\title{
$\mathrm{UiO}$ : Det juridiske fakultet
}

\section{Språklige valg ved gjennomføring av barnekonvensjonen artikkel 12 i norsk lovgivning}

Kandidatnummer: 610

Leveringsfrist: 25.11.2019

Antall ord: 17978 


\section{Innholdsfortegnelse}

1 INNLEDNING ..................................................................................................... 1

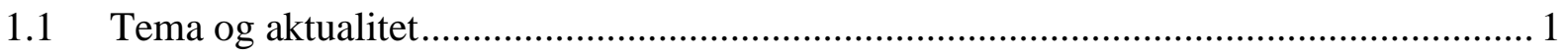

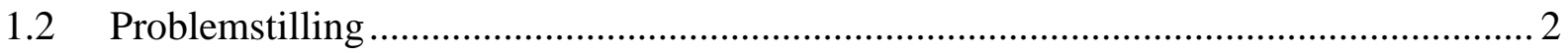

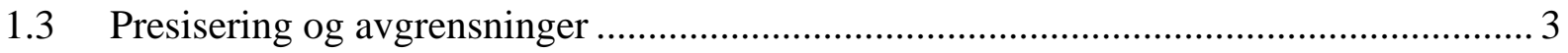

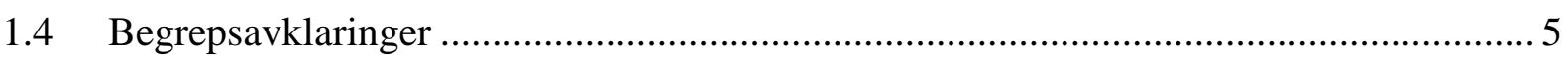

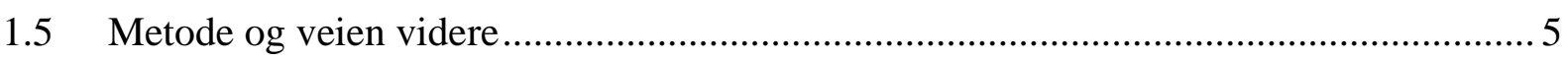

2 GJENNOMFØRING AV FOLKERETT I NORSK RETT ...................................8

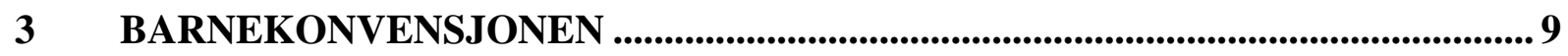

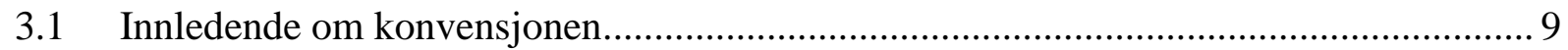

3.2 Gjennomføring av barnekonvensjonen i norsk lovgivning ........................................ 10

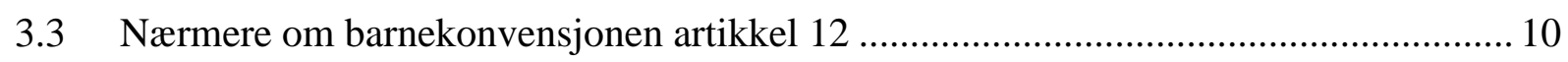

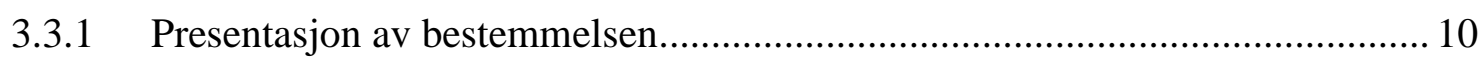

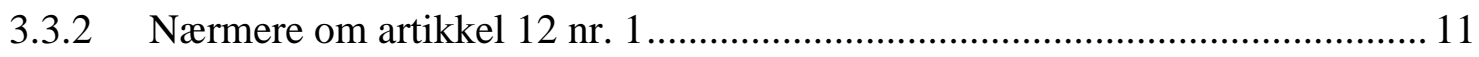

4 FORMULERINGER AV BARNS RETT TIL Å BLI HØRT I NORSK

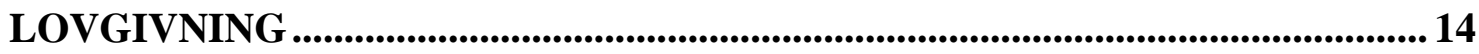

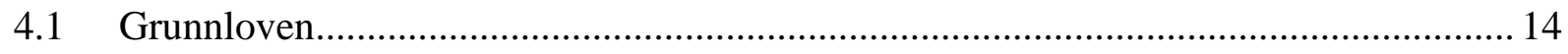

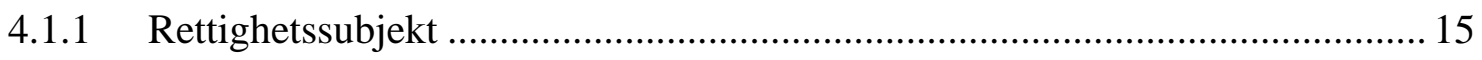

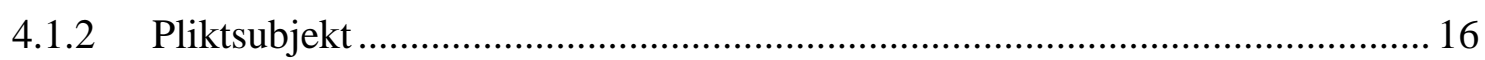

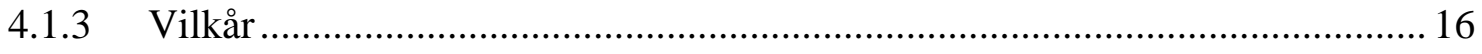

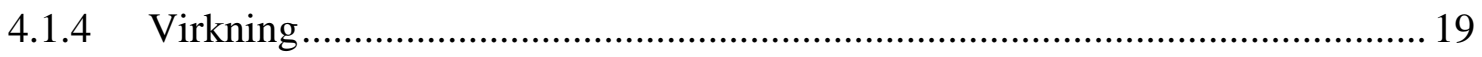

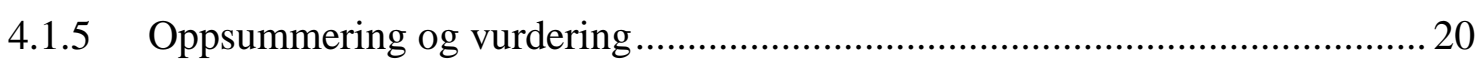

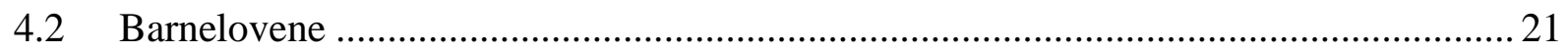

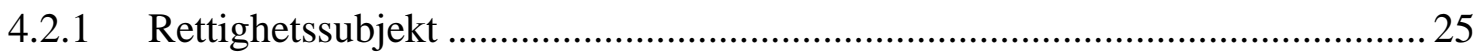

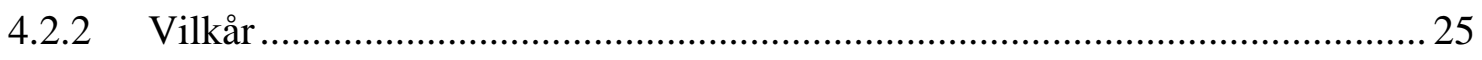

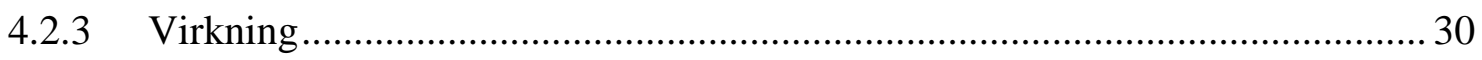

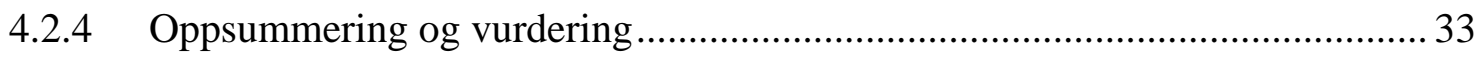

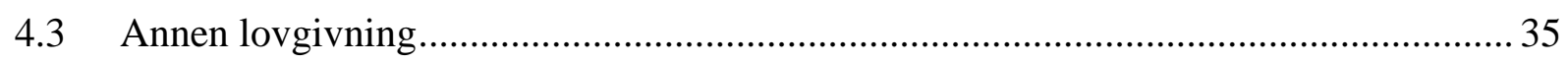

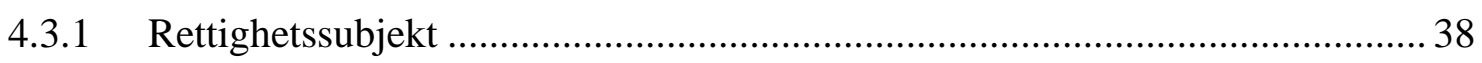

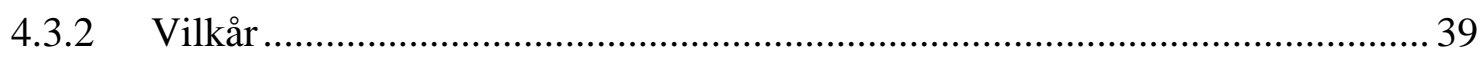

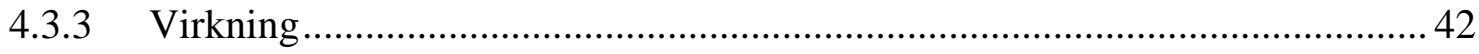

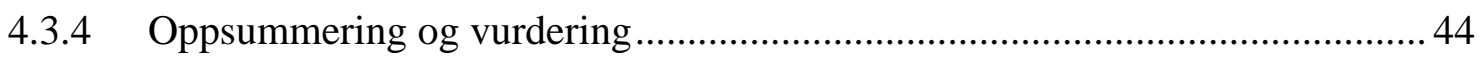

5 AVSLUTTENDE VURDERINGER ........................................................................4 45 
KILDELISTE .........................................................................................................................................5 50

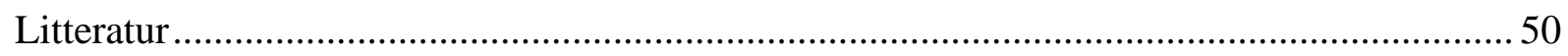

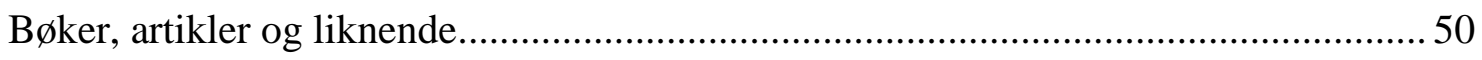

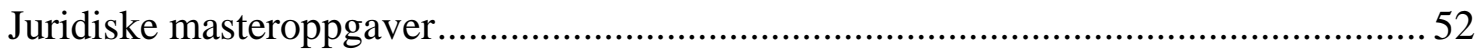

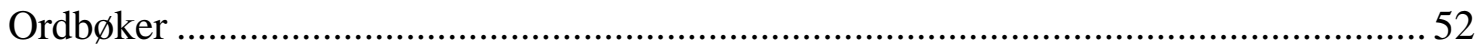

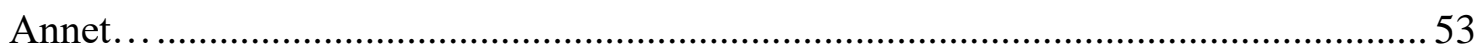

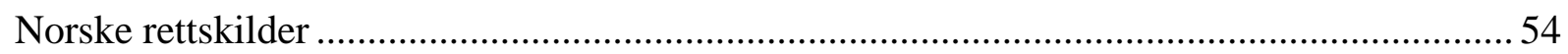

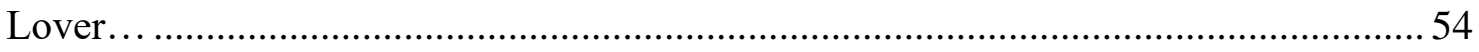

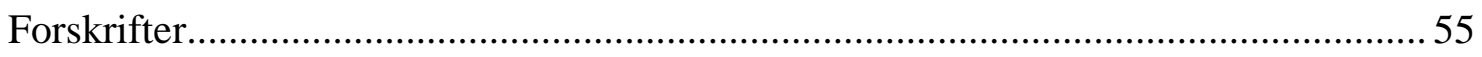

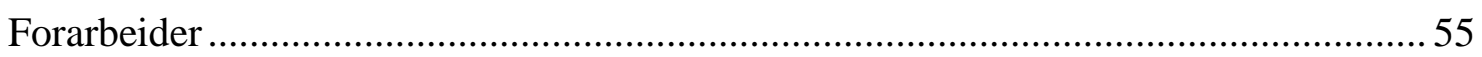

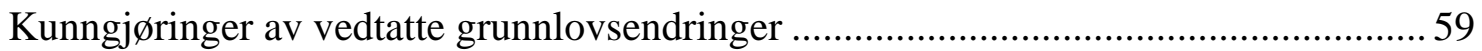

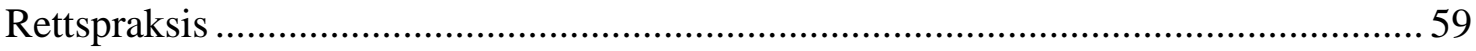

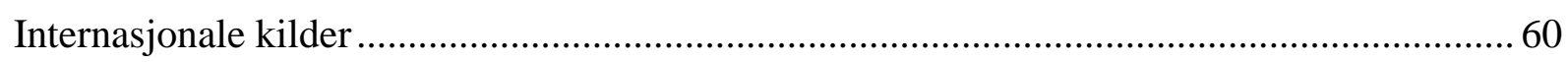

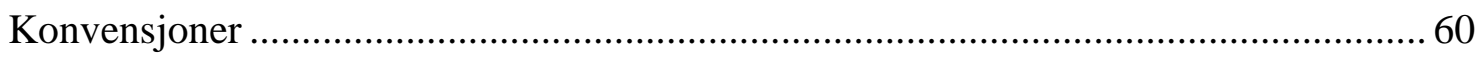

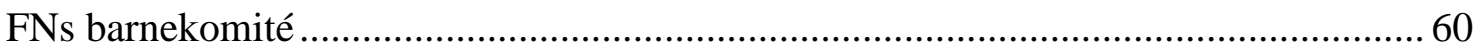




\section{$1 \quad$ Innledning}

\section{$1.1 \quad$ Tema og aktualitet}

Tema for oppgaven er lovgivers språklige valg ved gjennomføring av folkerettsbestemmelser i norsk lovgivning.

Folkeretten påvirker nasjonal lovgivning. Dette kalles gjerne rettslig globalisering eller internasjonalisering, som kan beskrives som en prosess som innebærer større grad av internasjonalt samarbeid og gjensidig rettslig påvirkning, og at dette samarbeidet institusjonaliseres. ${ }^{1}$ I Norge er særlig utviklingen av EU-retten og fremveksten av internasjonale menneskerettigheter viktige rettslige globaliseringsprosesser. ${ }^{2}$ Et resultat av disse prosessene er at en betydelig del av norsk lovgivning er gjennomføring av folkerettsbestemmelser. ${ }^{3}$

Menneskerettsloven (mrl. $)^{4}$ er et eksempel på rettslig globalisering. Paragraf 2 sier at en rekke menneskerettighetskonvensjoner gjelder som norsk lov. Dette er én av flere metoder for gjennomføring av folkerett i norsk lovgivning. Flere av metodene innebærer at rettigheter og plikter som følger av folkerettsbestemmelser oversettes. Se mer om dette i kapittel 2.

Det er flere spørsmål som oppstår ved gjennomføring av folkerettslige forpliktelser. For eksempel hvordan man sikrer at innholdet i folkerettsbestemmelser gjennomføres tilstrekkelig og i tråd med intensjonen, og hvordan man sikrer at språket i lovgivningen som plasseres blant annen norsk lovgivning er forståelig, samt at det er i tråd med det norske lovspråket. Et annet interessant spørsmål er hva som skjer med norsk lovspråk når stadig mer av lovgivningen er gjennomføring av folkerettsbestemmelser. Disse spørsmålene har vært viktige utgangspunkter for arbeidet med oppgaven.

Oppgavens tema er aktuelt nettopp på grunn av rettslig globalisering. Videre er det aktuelt fordi det i Norge de siste årene har vært $\varnothing$ kende oppmerksomhet om juridisk språk, og det som omtales som klarspråk. Språkrådet definerer klarspråk som «korrekt, klart og mottakertilpasset språk i tekster fra det offentlige». ${ }^{5}$ Det er de siste ti årene startet flere prosjekter om klarspråk og klart lovspråk, som har inspirert denne oppgaven. ${ }^{6}$

\footnotetext{
Blandhol (2005) s. 317-318, Michalsen (2001) s. 453, Østerud (2006) s. 616.

Blandhol (2005) s. 317-318.

Se f.eks. NOU 2012: 2 s. 118.

4 Lov 21. mai 1999 om styrking av menneskerettighetenes stilling i norsk rett.

5 Språkrådet (2013) s. 2.

6 Språkrådet (u.å.), Kvarenes (2009), Difi (2015), KMD (2016).
} 
Som spørsmålene ovenfor viser, er det aktuelt å se klart lovspråk og rettslig globalisering i sammenheng. Samtidig er både disse spørsmålene og temaet presentert innledningsvis for omfattende for en masteroppgave. Oppgavens problemstilling dreier seg derfor om gjennomføringen av én bestemt folkerettsbestemmelse.

\subsection{Problemstilling}

Jeg vil vurdere lovgivers språklige valg ved gjennomføringen av barns rett til å bli hørt som følger av artikkel 12 i De forente nasjoners internasjonale konvensjon 20. november 1989 om barnets rettigheter (barnekonvensjonen eller BK).

Bakgrunnen er at barns rettigheter har fått mer oppmerksomhet de siste årene. ${ }^{7}$ En viktig årsak er barnekonvensjonen, som er ratifisert av de fleste stater. ${ }^{8}$ Videre er barns rett til å bli hørt inntatt i en rekke norske lover på forskjellige rettsområder, og med ulike formuleringer. Retten til å bli hørt er både inntatt i lover som dreier seg spesielt om barn, for eksempel barnelova (bl. $)^{9}$ $\S 31$, og i lover som ikke handler spesielt om barn, men som har bestemmelser hvor barns rettigheter kommer til uttrykk, for eksempel forvaltningsloven (fvl.) ${ }^{10} \S 17$. I 2014 ble retten til å bli hørt også inntatt i Grunnloven (Grl.) ${ }^{11} \S 104$. Samlet gir dette et godt grunnlag for å vurdere lovgivers språklige valg ved gjennomføringen.

Det er interessant å se på en rettighet som er gjennomført i flere bestemmelser og på ulike rettsområder fordi man da både kan vurdere om lovgivers språklige valg er i tråd med konvensjonsteksten, og om språkvalgene i de norske bestemmelsene er konsekvent.

Vurderingen av lovgivers språklige valg gjøres gjennom å forsøke å besvare følgende spørsmål:

- Er det språklig variasjon mellom barnekonvensjonen artikkel 12 og de norske bestemmelsene?

- Er språket i de norske bestemmelsene dekkende?

- Er språket i de norske bestemmelsene enhetlig?

- Gir de språklige valgene språklig uklarhet?

7 Barns rettigheter og gjennomføringen av dem i norsk rett er beskrevet av flere, se f.eks. Smith (2008) s. 8495, Smith (2016) s. 29 og Sandberg (2016) s. 121.

$8 \quad$ Smith (2008) s. 84.

9 Lov 8. april 1981 om barn og foreldre.

10 Lov 10. februar 1967 om behandlingsmåten i forvaltningssaker.

11 Lov 17. mai 1814 Kongeriket Norges Grunnlov. 
- Gir de språklige valgene rettsusikkerhet?

- Har de språklige valgene rettslig betydning?

- Hva forklarer eventuell språklig variasjon mellom artikkel 12 og de norske bestemmelsene, og mellom disse bestemmelsene?

- Hvilke vurderinger er gjort ved gjennomføringen av rettigheten i de norske bestemmelsene?

- Er språket i de norske bestemmelsene gjennomtenkt?

- I hvilken grad er lovgivers språkarbeid systematisk?

Spørsmålene er relevante av flere grunner. Dersom språket i bestemmelsene varierer, kan det være vanskelig for lesere å finne frem til bestemmelsene de trenger, forstå bestemmelsene og ikke minst å bruke dem. Da er ikke rettigheten gjennomført i klarspråk. ${ }^{12}$ Aktuelle lesere er en stor og variert gruppe; i tillegg til jurister er det blant annet barn, foreldre, barnevernspedagoger, lærere og helsepersonell.

Videre kan språklige forskjeller ha innholdsmessig, altså rettslig, betydning. Rettslige forskjeller kan igjen ha betydning for bestemmelsenes effektivitet. Språklig og innholdsmessig variasjon kan også skape rettsusikkerhet, som påvirker rettssikkerheten til barn i Norge.

\subsection{Presisering og avgrensninger}

Både oppgavens omfang og problemstilling gjør det nødvendig å avgrense, og å presisere problemstillingen nærmere.

Det er språket i bestemmelsene som er oppgavens fokus, og ikke hva som er gjeldende rett. Dette henger riktignok sammen, fordi språket har betydning for innholdet. Men oppgaven handler ikke om å avklare hva som er gjeldende rett. ${ }^{13}$

Temaet er lovgivers språklige valg i de forskjellige bestemmelsene, og om disse valgene er i tråd med språket i konvensjonsbestemmelsen og med hverandre. Jeg vurderer ikke om språket i hver bestemmelse er utformet klart, men om lovgivers språklige valg innebærer at språket i bestemmelser om retten til å bli hørt i norsk lovgivning samlet sett fremstår som klart, og i overensstemmelse med konvensjonsbestemmelsen og med hverandre.

\footnotetext{
12 Språkrådet (2013) s. 2.

13 Avgrensningen er inspirert av Carlsen (2018) s. 2.
} 
Heller ikke spørsmål om språklig stil blir behandlet, altså om de språklige valgene er gjort på en slik måte at de er i tråd med norsk lovspråk og språket i den aktuelle loven for øvrig. ${ }^{14}$

Uttrykkene «rett til å bli hørt» og «rett til medbestemmelse» eller «medvirkning» benyttes ofte om hverandre. Samtidig er det å bli hørt ikke bare en forutsetning for medbestemmelse, men også for selvbestemmelse. Barnekonvensjonen artikkel 12 gir bare rett til førstnevnte. ${ }^{15} \mathrm{Be}-$ stemmelser eller deler av bestemmelser som omhandler barns rett til selvbestemmelse behandles ikke, for eksempel adopsjonsloven (adl.) ${ }^{16} \S 9$ (2). Selvbestemmelse nevnes heller ikke i FNs komité for barnets rettigheter (barnekomiteen) sin generelle kommentar om artikkel 12 $2^{17}$, heretter generell kommentar nr. 12, hvor komiteen foretar en juridisk analyse av artikkel 12. Se mer om barnekomiteen og generelle kommentarer i kapittel 3.1.

Artikkel 12 gir heller ikke barn partsrettigheter, ${ }^{18}$ og partsrettigheter nevnes ikke i generell kommentar nr. 12. Bestemmelser eller deler av bestemmelser som omhandler dette behandles derfor i utgangspunktet ikke, for eksempel barnevernloven (bvl.) ${ }^{19} \S 6-3$ (2).

Heller ikke bestemmelser eller deler av bestemmelser som dreier seg om situasjoner hvor barnet har representant, verge eller liknende behandles, med unntak av bestemmelser i vergemålsloven (vgml. $)^{20}$. Representanter nevnes i artikkel 12 nr. 2, men det er ikke anledning til å gå nærmere inn på dette.

Spørsmålet om barn har en eventuell plikt til å uttale seg behandles ikke, bortsett fra helt kort i kapittel 3.3.2.4 om konvensjonsbestemmelsen. Jeg bemerker likevel at de norske bestemmelsene som behandles ikke oppstiller en slik plikt. For enkelte bestemmelser, som bl. $\S 31$ og bvl. §1-6, er dette også presisert i forarbeidene. ${ }^{21}$

Mulige unntak fra retten til å bli hørt faller også utenfor oppgaven.

14 Se mer i Bangsund (2010) s. 22.

15 UNICEF (2007) s. 150, Sandberg (2016) s. 93.

16 Lov 16. juni 2017 om adopsjon.

17 General Comment No. 12 (2009) The right of the child to be heard CRC/C/GC/12.

18 NOU 2011: 20 s. 21.

19 Lov 17. juli 1992 om barneverntjenester.

20 Lov 26. mars 2010 om vergemål.

21 Bl. § 31: Innst.O. nr. 30 (1980-1981) s. 9, Ot.prp. nr. 29 (2002-2003) s. 61-62, Prop. 85 L (2012-2013) s. 35. Bvl. § 1-6: Prop. 169 L (2016-2017) s. 40 og 142. 
En norsk oversettelse av barnekonvensjonen er inntatt i vedlegg 8 til menneskerettsloven. Denne blir ikke vurdert ettersom det ikke er en offisiell språkversjon, ${ }^{22}$ men blir vist til der det er relevant.

\section{$1.4 \quad$ Begrepsavklaringer}

Artikkel 12 gir uttrykk for en rettighet og et prinsipp som omtales og formuleres på forskjellige måter, jfr. kapittel 1.3. Jeg bruker uttrykket «barns rett til å bli hørt» når rettigheten generelt omtales. Når jeg viser til bestemte termer i ulike bestemmelser, benyttes disse termene.

Det vises flere steder til «barnelovene» og «annen lovgivning». Med «barnelovene» menes lover som omhandler barn spesielt, som barneloven. «Annen lovgivning» viser til lover som ikke dreier seg om barn spesielt, men som har bestemmelser hvor retten til å bli hørt er inntatt, som fvl. § 17 (1) annet og tredje punktum.

Når det står at noe i en norsk bestemmelse «tilsvarer» noe i barnekonvensjonen, betyr det verken at formuleringen eller innholdet nødvendigvis er det samme, men at det er fellestrekk, for eksempel at begge er objektive vilkår. Dersom formuleringene er like, beskrives det som en direkte oversettelse. Samtidig er ikke nødvendigvis betydningen identisk selv om det er en direkte oversettelse. For eksempel kan «child» og «barn» omfatte forskjellige personer. Derfor kan det ved direkte oversettelser likevel være nødvendig å vurdere innholdet $\mathrm{i}$ termene nærmere.

Med «lovgiver» menes alle som deltar i forberedelse av ny lovgivning.

\subsection{Metode og veien videre}

I kapittel 2 gis en kort oversikt over gjennomføring av folkerett i norsk lovgivning. Deretter følger kapittel 3 om barnekonvensjonen. Kapittel 3.1 omhandler konvensjonen generelt, for å sette artikkel 12 i kontekst. I kapittel 3.2 presenteres kort gjennomføringen av barnekonvensjonen i norsk lovgivning. Kapittel 3.3 presenterer språket og innholdet i artikkel 12. Dette er nødvendig fordi resten av oppgaven er en språklig sammenlikning av norske bestemmelser opp mot konvensjonsbestemmelsen.

22 Jfr. barnekonvensjonen artikkel 54. Se mer i kap. 3.1. 
Kapittel 4 dreier seg om barns rett til å bli hørt i norsk lovgivning. Rettigheten kommer til uttrykk i en rekke bestemmelser, som Grl. § 104 (1) annet punktum, adl. § 9 (1), barnebortføringsloven (bbfl.) ${ }^{23} \S 17$ (1), barnehageloven (bhl.) ${ }^{24} \S \S 1$ (2) tredje punktum og 3, bl. $\S 31$, bvl. $\S$ 1-6 første til tredje punktum og 6-3 (1), fvl. § 17 (1) annet og tredje punktum, kommuneloven (koml. $)^{25} \S 7-2$ (5), lov om trudomssamfunn og ymist anna (lotr.) ${ }^{26} \S 6$ (4), opplæringslova (oppll.) ${ }^{27} \S \S 1-1$ (6) annet punktum, 9 A-4 (5) første punktum, 9 A-6 (1), 9 A-8, 9 A-9 (3), 11-1 (1) og (2), 11-2, 11-5 (1) og (2), 11-5a, 11-6, 11-8, pasient- og brukerrettighetsloven (pbrl.) $)^{28} \S \S 3-1$ (1) fjerde og femte punktum og 4-4 (5), plan- og bygningsloven (pbl.) ${ }^{29}$ §§ 3-3 (3) og 5-1 (2) første punktum, vgml. §§ 17 (4) første punktum og 19 (1) tredje punktum og utlendingsforskriften (utf.) $)^{30} \S 17-3$ (1) og (3), jfr. utlendingsloven (utl.) ${ }^{31} \S 81$ (2).

Selv om fvl. § 17 (1) annet og tredje punktum dreier seg om retten til å bli hørt for barn som er parter, blir den likevel behandlet fordi forvaltningsloven er en sentral lov, og det derfor har verdi å se nærmere på en bestemmelse her. Fvl. § 16 (1) annet punktum dreier seg om mindreåriges rett til å bli hørt i situasjoner hvor den mindreårige både er part og representeres av verge, og er derfor ikke inntatt, jfr. kapittel 1.3. Heller ikke tvisteloven (tvl.) ${ }^{32} \S \S 2-4$ (2) og 14 (1) er inntatt, fordi de gir rett til innsyn, men ikke til å uttale seg. ${ }^{33}$

Oppgavens omfang gjør det umulig å behandle alle bestemmelsene like inngående. Jeg har derfor gjort et utvalg, med mål om å trekke frem sentrale bestemmelser som berører mange barn, og samtidig få frem bredden i både rettsområder og formuleringer.

Bestemmelsene som er hovedtema for oppgaven er: Grl. § 104 (1) annet punktum, bl. § 31, bvl. § 1-6 første til tredje punktum, fvl. § 17 (1) annet og tredje punktum, oppll. § 1-1 (6) annet punktum, pbrl. § 4-4 (5) og vgml. § 17 (4) første punktum. De andre bestemmelsene vises det kort til i petitavsnitt der det er relevant.

\footnotetext{
23 Lov 8. juli 1988 om anerkjennelse og fullbyrding av utenlandske avgjørelser om foreldreansvar $\mathrm{m} v$ og om tilbakelevering av barn.

24 Lov 17. juni 2005 om barnehager.

25 Lov 22. juni 2018 om kommuner og fylkeskommuner.

26 Lov 13. juni 1969 om trudomssamfunn og ymist anna.

27 Lov 17. juli 1998 om grunnskolen og den vidaregåande opplæringa.

28 Lov 2. juli 1999 om pasient- og brukerrettigheter.

29 Lov 27. juni 2008 om planlegging og byggesaksbehandling.

30 Forskrift 15. oktober 2009 om utlendingers adgang til riket og deres opphold her.

31 Lov 15. mai 2008 om utlendingers adgang til riket og deres opphold her.

32 Lov 17. juni 2005 om mekling og rettergang i sivile tvister.

33 Tvl. § 22-3 a (2) viser for $\emptyset$ vrig til vgml. § 17 (2) og bl. § 31.
} 
I opplæringslova er det mange bestemmelser om retten til å bli hørt. Jeg har derfor valgt å kun se på formålsbestemmelsen. De andre nevnes ikke i den videre fremstillingen.

I kapittel 4.1 behandles retten til å bli hørt i Grunnloven, i kapittel 4.2 i barnelovene og i kapittel $4.3 \mathrm{i}$ annen lovgivning. Kapitlene har innledningsvis en skjematisk fremstilling av bestemmelsene, inndelt i rettighetssubjekt, pliktsubjekt, vilkår og virkning. På denne måten tydeliggjøres likheter og forskjeller mellom konvensjonsbestemmelsen og norske bestemmelser, og mellom de norske bestemmelsene. Også bestemmelsene som ikke er hovedtema inntas i skjemaet.

For hvert av disse punktene foretas en språklig analyse av bestemmelsene som er hovedtema. Utgangspunktet for analysen er, i tråd med alminnelig norsk rettskildelære, den naturlige, språklige forståelsen av ordlyden. ${ }^{34}$ Der betydningen av et ord er uklar, suppleres det med ordboken. Dersom bestemmelsens formulering skiller seg fra konvensjonsbestemmelsens formulering, ser jeg om lovgiver i forarbeidene har sagt noe om språkvalget og forståelsen av ordlyden, og hvilke vurderinger lovgiver har gjort ved valget av formulering. Jeg analyserer ikke bestemmelsene som er utenfor mitt fokus, men enkelte steder viser jeg kort til uttalelser i forarbeidene.

Dersom lovgivers språklige valg avviker fra artikkel 12, går jeg til rettspraksis for å se hva rettsanvender sier om språket i bestemmelsene, hvor bevisste de er på språklige ulikheter, og om språklige endringer gir seg utslag i praksis. Mengden rettspraksis om de forskjellige bestemmelsene varierer veldig. Jeg ser i utgangspunktet på høyesterettspraksis, men der dette ikke finnes, eller der høyesterettspraksis ikke behandler retten til å bli hørt, ser jeg på praksis fra lagmannsrettene. Dersom heller ikke lagmannsrettspraksis behandler rettigheten, ser jeg om den behandles i tingrettspraksis. Utvalget er begrenset til rettspraksis tilgjengelig på Lovdata, sist sjekket 16. november 2019, fra etter siste endring av den aktuelle bestemmelsen. Det er også interessant å se på forvaltningspraksis, men oppgavens omfang gjør at det ikke er anledning til dette.

Bestemmelsene blir fortløpende sammenliknet med artikkel 12 i den offisielle, engelske versjonen av konvensjonen, bortsett fra formuleringen av pliktsubjektet $\mathrm{i}$ barnelovene og annen lovgivning, hvor en sammenlikning har lite for seg. Se mer om dette i kapittel 3.3.2.2. Der det er hensiktsmessig sammenlikner jeg også med den norske oversettelsen som er inntatt i vedlegg 8 til menneskerettsloven, fordi denne kan si noe om hvordan konvensjonsbestemmelsen forstås i Norge.

34 Aarli og Mæhle (2018) s. 140, Mestad (2019) s. 81. 
De norske bestemmelsene blir i utgangspunktet sammenliknet med artikkel $12 \mathrm{nr}$. 1, fordi nr. 1 er utgangspunktet, mens nr. 2 er en spesifisering av rettigheten i enkelte konkrete tilfeller. Se mer om dette i kapittel 3.3.1.

Avslutningsvis i kapitlene 4.1, 4.2 og 4.3 oppsummeres funnene.

I kapittel 5 besvares spørsmålene oppstilt i problemstillingen.

\section{$2 \quad$ Gjennomføring av folkerett i norsk rett}

Utgangspunktet for forholdet mellom norsk rett og folkerett er det dualistiske prinsipp, som går ut på at folkerett og nasjonal rett er adskilte rettssystemer. Dette innebærer at norske domstoler skal anvende norsk rett, og ved motstrid mellom norsk rett og folkerett må sistnevnte vike. Utgangspunktet er modifisert, blant annet ved at folkerett kan vedtas som norsk rett, og ved utviklingen av presumsjonsprinsippet, hvor norsk rett presumeres å samsvare med folkerettslige regler. ${ }^{35}$

Ruud og Ulfstein beskriver ulike metoder for å vedta folkerettslige regler som norsk rett. Én metode er aktiv transformasjon, hvor konvensjonsbestemmelser gjengis i norsk lov i norsk oversettelse. En annen er inkorporasjon, hvor folkerettslige regler gjøres til norsk rett ved å henvise til den aktuelle traktaten, slik det er gjort i mrl. § 2. Et tredje alternativ er passiv transformasjon, hvor man konstaterer at norsk rett er i tråd med de folkerettslige reglene. ${ }^{36}$

Oversettelse er nødvendig ved aktiv transformasjon, men kan også være aktuelt ved inkorporasjon; i tillegg til at det henvises til den aktuelle konvensjonen eller traktaten i en lovbestemmelse, slik som i mrl. § 2, kan det være nødvendig å gjøre endringer andre steder i norsk lovgivning for at lovverket skal være i tråd med konvensjonsforpliktelsen.

35 Ruud og Ulfstein (2018) s. 55 og 59.

36 Ibid. s. 61-65. 


\section{Barnekonvensjonen}

\subsection{Innledende om konvensjonen}

Barnekonvensjonen gir barn en rekke rettigheter, og er rettslig bindende for stater som ratifiserer den. ${ }^{37}$ Også de andre menneskerettighetskonvensjonene gjelder for barn, men der kommer det ikke tydelig frem at barn er spesielt sårbare og har spesielle behov. ${ }^{38}$ Noen konvensjoner har riktignok inntatt egne artikler om barn, som De forente nasjoners internasjonale konvensjon 16. desember 1966 om sivile og politiske rettigheter (SP) artikkel 24 om barns rett til beskyttelse, et navn og nasjonalitet. Det spesielle med barnekonvensjonen er at den har klarlagt barns stilling som egne rettssubjekter. ${ }^{39}$ Konvensjonen gir også spesielle rettigheter for barn der det er nødvendig, for eksempel retten til å bli hørt. ${ }^{40}$

Det er fire generelle prinsipper eller verdier som gjelder for hele barnekonvensjonen, og disse kommer til uttrykk i fire av artiklene: retten til ikke-diskriminering i artikkel 2, prinsippet om at barnets beste skal være et grunnleggende hensyn i artikkel 3, retten til liv og utvikling i artikkel 6 og retten til å bli hørt i artikkel $12 .{ }^{41}$ At de utgjør generelle prinsipper innebærer at de både skal tas hensyn til ved tolkningen og gjennomføringen av de andre rettighetene i konvensjonen, og er selvstendige rettigheter. ${ }^{42}$

Videre er det vanlig å dele rettighetene i konvensjonen inn i tre kategorier, ofte kalt de tre Pene: provision, protection og participation.$^{43}$ Dette kan oversettes til omsorg, beskyttelse og deltagelse. ${ }^{44}$ Barnekonvensjonen artikkel 12 tilhører kategorien av rettigheter som omhandler deltagelse. $^{45}$

Utgangspunktet for tolkningen av konvensjonen er, i likhet med norsk lovgivning, en naturlig, språklig forståelse av ordene ${ }^{46}$ Fordi mange av bestemmelsene i barnekonvensjonen er lite

\footnotetext{
37 Smith (2016) s. 17.

38 Dokument 16 (2011-2012) s. 186.

39 Høstmælingen, Kjørholt og Sandberg (2016) forord.

40 Høstmælingen, Kjørholt og Sandberg (2016) forord.

41 Generell kommentar nr. 12 avsn. 2.

42 Generell kommentar nr. 12 avsn. 2, Sandberg (2016) s. 92.

43 Generell kommentar nr. 12 s. 8, Haugli (2010) s. 9.

44 Generell kommentar nr. 12 s. 8.

45 Haugli (2010) s. 9.

46 Wien-konvensjonen om traktatretten av 23. mai 1969 art. 31 nr. 1, Smith (2016) s. 24.
} 
presise, og fordi det ikke har vært noen egen domstol eller klageordning, er innholdet i flere av artiklene usikkert. ${ }^{47}$ Barnekomiteen, konvensjonens overvåkingsorgan, utgir generelle kommentarer om tolkningen av enkeltartikler eller spesielt viktige spørsmål. Kommentarene er ikke rettslig bindende, men gir god veiledning for fastleggingen av artiklenes innhold, og er viktige kilder for tolkning av konvensjonen. De blir også i økende grad vist til av norske domstoler. ${ }^{48}$

Konvensjonen finnes i seks offisielle og likeverdige språkversjoner; arabisk, engelsk, fransk, kinesisk, russisk og spansk. ${ }^{49}$ I menneskerettsloven er den engelske språkversjonen inntatt i vedlegg 7 .

\subsection{Gjennomføring av barnekonvensjonen i norsk lovgivning}

Barnekonvensjonen trådte i kraft i Norge i 1991, og ble inkorporert i 2003 gjennom mrl. § 2 nr. 4. ${ }^{50}$ Ved motstrid går barnekonvensjonen foran bestemmelser i «annen lovgivning», jfr. mrl. $\S 3$. Konvensjonene som er inkorporert gjennom menneskerettsloven er blitt omtalt som semikonstitusjonelle; ${ }^{51}$ de går ved motstrid foran alminnelig lovgivning, men går ikke foran Grunnloven, jfr. lex superior-prinsippet. ${ }^{52}$ Barnekonvensjonen står altså sterkt i norsk rett. ${ }^{53}$

Barnekonvensjonen ble gjennomført ved passiv transformasjon. ${ }^{54} \mathrm{Da}$ den senere ble inkorporert, ble det gjort endringer i flere lover for å gjøre konvensjonsrettighetene synligere i norsk lovgivning. 55

\subsection{Nærmere om barnekonvensjonen artikkel 12}

\subsubsection{Presentasjon av bestemmelsen}

Artikkel 12 lyder:

47 Smith (2016) s. 24.

48 Smith (2016) s. 18 og 25. I HR-2018-2096-A har Høyesterett uttalt seg om den rettskildemessige vekten til barnekomiteens generelle kommentarer, se særlig avsn. 14. Se også Rt. 2015 s. 1388 avsn. 151 og Rt. 2009 s. 1261 avsn. 40-44.

49 Jfr. barnekonvensjonen artikkel 54. Se mer i Ruud og Ulfstein (2018) s. 96.

50 Høstmælingen, Kjørholt og Sandberg (2016) forord, Smith (2016) s. 18 og 27.

51 Smith (1999) s. 272.

52 Aarli og Mæhle (2018) s. 178, Smith (1999) s. 272.

53 Smith (2016) s. 27.

54 Backer (2002) s. 69.

55 Smith (2016) s. 27. 
«1. States Parties shall assure to the child who is capable of forming his or her own views the right to express those views freely in all matters affecting the child, the views of the child being given due weight in accordance with the age and maturity of the child.

2. For this purpose, the child shall in particular be provided the opportunity to be heard in any judicial and administrative proceedings affecting the child, either directly, or through a representative or an appropriate body, in a manner consistent with the procedural rules of national law.»

Nr. 2 dreier seg spesielt om retten til å bli hørt i rettslig og administrativ saksbehandling, og må tolkes i lys av nr. $1 .{ }^{56}$ De norske bestemmelsene sammenliknes derfor i hovedsak med nr. 1. Samtidig er det også relevant å sammenlikne dem med nr. 2, fordi flere av bestemmelsene omfatter saksbehandling. Likheter mellom de norske bestemmelsene og nr. 2 blir derfor påpekt, selv om den videre fremstillingen av artikkel 12 er konsentrert om nr. 1.

Artikkel 12 nr. 1 kan settes opp skjematisk slik:

\begin{tabular}{|c|c|c|c|}
\hline Rettighetssubjekt & Pliktsubjekt & Vilkår & Virkning \\
\hline «the child» & «States Parties» & $\begin{array}{l}\text { 1) «capable of forming } \\
\text { his or her own views» } \\
\text { 2) «matters affecting the } \\
\text { child» }\end{array}$ & $\begin{array}{l}\text { 1) «right to express those } \\
\text { views freely» } \\
\text { 2) «the views of the child } \\
\text { being given due weight } \\
\text { in accordance with the } \\
\text { age and maturity of the } \\
\text { child» }\end{array}$ \\
\hline
\end{tabular}

Analysen av artikkel 12 nr. 1 deles inn skjemaets fire kategorier. Hver del starter med en ordlydstolkning, med hjelp fra ordboken ved uklarheter. Deretter ser jeg hva barnekomiteen har uttalt i generell kommentar nr. 12.

\subsubsection{Nærmere om artikkel $12 \mathrm{nr} .1$}

$56 \quad$ Sandberg (2016) s. 101. 


\subsubsection{Rettighetssubjekt}

Artikkel 12 nr. 1 gjelder for barn, jfr. «the child». Barn defineres i barnekonvensjonen artikkel 1 som personer under 18 år. Bruken av bestemt form entall trekker i retning av at rettigheten er individuell. Men barnekomiteen uttaler i generell kommentar nr. 12 avsnitt 9 at retten til å bli hørt både gjelder for enkeltindivider og for barn som opptrer i gruppe for å ivareta interessene sine ${ }^{57}$ Retten til å bli hørt som gruppe gjelder både når barn uttaler seg om interessene til en gruppe barn og når de uttaler seg om interessene til barn generelt. ${ }^{58}$

\subsubsection{Pliktsubjekt}

Det er konvensjonspartene, altså statene, som er pliktsubjekter, jfr. «States Parties shall assure». I avsnitt 19 i den generelle kommentaren uttaler barnekomiteen at «shall assure» innebærer at det er en streng forpliktelse for konvensjonspartene, som både innebærer å sikre mekanismer hvor barn har mulighet til å uttrykke sine synspunkter, og å tillegge synspunktene den påkrevede vekten. Statene har altså en positiv forpliktelse til å sikre rettigheten, til forskjell fra rett til ytringsfrihet etter artikkel 13, som innebærer en rett til fravær av inngrep. ${ }^{59}$

Staten Norge overholder sin forpliktelse gjennom å vedta bestemmelser som sikrer barns rett til å bli hørt; i Grunnloven, gjennom inkorporeringen av barnekonvensjonen i menneskerettsloven og i ulike særlover. Pliktsubjektene i sistnevnte er derfor mange og varierte, uten nødvendigvis å være i strid med artikkel 12 .

\subsubsection{Vilkår}

Ordlyden i nr. 1 tilsier at det er to vilkår, eller forutsetninger, for at rettigheten aktualiseres; barnet må være «capable of forming his or her own views», og det må gjelde «matters affecting the child». Det samme fremgår av avsnitt 26 i den generelle kommentaren.

Det første vilkåret er subjektivt, og sier at barnet må være i stand til å danne seg egne synspunkter. Det står ikke at det må være synspunkter på det aktuelle spørsmålet, men det er likevel naturlig å forstå det som synspunkter på saken, og ikke bare et hvilket som helst synspunkt. For eksempel vil et lite barn kunne danne seg egne synspunkter om hvilke leker det liker best å leke med eller hva slags mat som smaker best - det er ikke dermed sagt at barnet er i stand til å danne seg synspunkter om foreldreansvaret. Det fremgår også av den generelle kommentaren avsnitt 21 annet kulepunkt at barnekomiteen mener barnet må ha synspunkter på den aktuelle

\footnotetext{
57 Se også Sandberg (2016) s. 97.

58 Sandberg (2016) s. 97.

59 1.c.
} 
saken. Videre understreker barnekomiteen i avsnitt 20 og 21 at formuleringen «capable of forming his or her own views» ikke er ment som en begrensning, og at artikkel 12 ikke setter noen aldersgrense. Komiteen fraråder å innføre aldersgrenser, både i lov og praksis, fordi dette kan begrense rettigheten. ${ }^{60}$ Den understreker at barn er i stand til å ha synspunkter selv om de ikke nødvendigvis kan uttrykke dem i ord, og at også ikke-verbale former for kommunikasjon skal anerkjennes. $^{61}$

Det andre vilkåret er objektivt. Ifølge Stor engelsk-norsk ordbok betyr «matter»sak, spørsmål eller forhold. ${ }^{62}$ Det oppgis også at «to affect» betyr å «berøre», «påvirke» og «innvirke på». ${ }^{63}$ Det er altså naturlig å forstå vilkåret slik at rettigheten aktualiseres i en rekke tilfeller; alt fra spørsmål som direkte angår barnet, for eksempel hvem av foreldrene det skal bo hos, til forhold som påvirker hele samfunnet, som klimaendringer. Barnekomiteen uttaler at «all matters affecting the child» skal tolkes vidt. ${ }^{64}$ Komiteen påpeker at arbeidsgruppen som laget utkastet til konvensjonen opprinnelig foreslo å innta en liste over i hvilke saker barns synspunkter skulle tas hensyn til for å sette en begrensning, men heller valgte å gå for «all matters affecting the child». ${ }^{65}$

\subsubsection{Virkning}

Dersom vilkårene er oppfylt, har barnet «the right to express those views freely». En naturlig forståelse av «freely» tilsier at barnet har rett til å uttrykke sine synspunkter uten føringer. Barnekomiteen sier at formuleringen innebærer at barn har rett til å uttrykke sin egen mening, uten press, og selv kan velge om de vil benytte seg av retten. ${ }^{66}$ Retten til å uttrykke seg omfatter som nevnt i kapittel 3.3.2.3 også ikke-verbale uttrykksformer. Komiteen sier også at rett til informasjon er en forutsetning for realisering av retten til å uttale seg, selv om informasjon ikke nevnes i konvensjonsteksten. ${ }^{67}$

Videre skal barnets synspunkter gis «due weight in accordance with the age and maturity of the child». En naturlig forståelse tilsier at synspunktene skal lyttes til og tas seriøst. I tillegg skal det foretas en individuell vurdering av synspunktenes vekt, hvor både barnets alder og modenhet har betydning. Barnekomiteen uttaler at det ikke er nok å høre på barna, men at syns-

\footnotetext{
60 Generell kommentar nr. 12 avsn. 21.

61 Generell kommentar nr. 12 avsn. 21 første kulepunkt.

62 Ordnett.no(a).

63 Ordnett.no(b).

64 Generell kommentar nr. 12 avsn. 26.

65 Ibid. avsn. 27.

66 Ibid. avsn. 22.

67 Ibid. avsn. 25.
} 
punktene skal tas alvorlig. ${ }^{68}$ Den definerer «maturity» som evnen til å uttrykke sine synspunkter i en sak på en fornuftig og selvstendig måte. ${ }^{69}$ Den sier videre at vekten av barnets synspunkter må vurderes i hvert enkelt tilfelle. ${ }^{70}$

Kombinasjonen av en rett til å uttrykke seg og at synspunktene skal vektlegges, gjør at man forstår at det er snakk om en rett til å bli hørt, selv om uttrykk som «right to be heard» eller liknende ikke er brukt i teksten. Det er også verdt å merke seg den generelle kommentarens undertittel «The right of the child to be heard». I artikkel 12 nr. 2 står det for $\varnothing v$ vrig «opportunity to be heard».

Artikkel 12 er formulert som en pliktbestemmelse for statene, jfr. «States Parties shall assure», og en rettighetsbestemmelse for barn, jfr. «right to express». Det fremgår tydelig av ordlyden at barn kun har en rett til å uttale seg, og ikke noen plikt. Dette bekreftes i den generelle kommentaren avsnitt 16 og 22.

\section{$4 \quad$ Formuleringer av barns rett til å bli hørt i norsk lovgivning}

\subsection{Grunnloven}

Paragraf 104 om barns rettigheter kom inn i Grunnloven i 2014, i forbindelse med at Grunnloven fikk et eget menneskerettighetskapittel. ${ }^{71}$ Retten til å bli hørt i § 104 (1) annet punktum er generell, i likhet med barnekonvensjonen artikkel 12 nr. 1.

Grl. § 104 (1) annet punktum lyder på bokmål:

«[Barn] har rett til å bli hørt i spørsmål som gjelder dem selv, og deres mening skal tillegges vekt i overensstemmelse med deres alder og utvikling.»

På nynorsk lyder bestemmelsen:

«[Born] har rett til å bli høyrde i spørsmål som gjeld dei sjølve, og det skal leggjast vekt på meininga deira i samsvar med alderen og utviklingsstedet.»

68 Ibid. avsn. 28.

69 Generell kommentar nr. 12 avsn. 30.

70 Ibid. avsn, 29.

71 FOR-2014-05-14-628, FOR-2014-06-20-778. 
En rask gjennomgang og sammenlikning av formuleringene viser at de to versjonene er like. Jeg tar utgangspunkt i bokmålsversjonen videre.

Her er en skjematisk fremstilling av artikkel 12 og Grl. § 104:

\begin{tabular}{|c|c|c|c|c|}
\hline & Rettighetssubjekt & Pliktsubjekt & Vilkår & Virkning \\
\hline BK art. 12 nr. 1 & «the child» & «States Parties» & $\begin{array}{l}\text { 1) «capable of } \\
\text { forming his or her } \\
\text { own views» } \\
\text { 2) «matters } \\
\text { affecting the child» }\end{array}$ & $\begin{array}{l}\text { 1) «right to express } \\
\text { those views freely» } \\
\text { 2) «the views of the } \\
\text { child being given } \\
\text { due weight in } \\
\text { accordance with the } \\
\text { age and maturity of } \\
\text { the child» }\end{array}$ \\
\hline $\begin{array}{l}\text { Grl. § } 104(1) \\
\text { annet pkt. }\end{array}$ & «[barn]», ${ }^{72} \ll$ de» & $\begin{array}{l}\text { «[statens myndig- } \\
\text { heter]» }{ }^{73}\end{array}$ & $\begin{array}{l}\text { «spørsmål som } \\
\text { gjelder dem selv» }\end{array}$ & $\begin{array}{l}\text { 1) «rett til å bli } \\
\text { hørt» } \\
\text { 2) «deres mening } \\
\text { skal tillegges vekt i } \\
\text { overensstemmelse } \\
\text { med deres alder og } \\
\text { utvikling» }\end{array}$ \\
\hline
\end{tabular}

\subsubsection{Rettighetssubjekt}

Grl. § 104 (1) annet punktum gir «[barn]» ${ }^{74}$ en rett til å bli hørt. Dette er en direkte oversettelse av «child». «Barn» er ikke definert i Grunnloven. En naturlig forståelse er personer som ikke har fylt 18 år, i likhet med barnekonvensjonen. I Dokument 16 (2011-2012) fra 2011 kom Stortingets Menneskerettighetsutvalg med forslag til nye menneskerettighetsbestemmelser i Grunnloven. Utvalget viser til barnekomiteens definisjon av «barn». ${ }^{75}$ Dette er ikke diskutert i rettspraksis. Det kan etter dette legges til grunn at «barn» i Grl. § 104 omfatter samme personer som «child» i barnekonvensjonen artikkel 12.

\footnotetext{
72 «Barn» står i Grl. § 104 (1) første pkt. «De» i annet pkt. viser tilbake til «barn».

73 Jfr. Grl. § 92.

74 «Barn» står i Grl. § 104 (1) første pkt. «De» i annet pkt. viser tilbake til «barn».

75 Dokument 16 (2011-2012) s. 187.
} 
Ordlyden trekker i retning av at grunnlovsbestemmelsen gir både en individuell og en kollektiv rettighet. Dette underbygges av at bestemmelsen er generell, i likhet med artikkel 12 som til tross for sin ordlyd både gir en individuell og kollektiv rettighet, jfr. kapittel 3.3.2.1. Menneskerettighetsutvalget uttaler at retten til å bli hørt etter $\S 104$ er ment som en individuell rettighet, og ikke som en kollektiv rettighet «der barn som gruppe har rett til å bli hørt dersom det offentliges beslutninger også berører dem som gruppe». ${ }^{76}$ Det samme synspunktet uttrykkes i Innst. 186 S (2013-2014) side 30. Samtidig sier Menneskerettighetsutvalget at «det bør imidlertid tas hensyn også til det en gruppe av barn måtte mene i en bestemt sak som berører denne gruppen særskilt.» ${ }^{77}$ Forarbeidene trekker altså i en annen, men ikke helt entydig, retning enn ordlyden. Dette er ikke diskutert i rettspraksis. Rettigheten etter $\S 104$ ser altså ut til å være individuell, og er derfor snevrere enn konvensjonsbestemmelsen.

\subsubsection{Pliktsubjekt}

Det følger av Grl. § 92, menneskerettighetskapittelets innledende bestemmelse, at «statens myndigheter» er pliktsubjekt. Dette samsvarer med artikkel 12.

\subsubsection{Vilkår}

Til forskjell fra barnekonvensjonen, oppstilles det i § 104 kun ett vilkår, nemlig at det må være snakk om «spørsmål som gjelder dem selv». Dette tilsvarer det objektive vilkåret i artikkel 12. «Spørsmål» er en oversettelse av «matter». ${ }^{78}$ En naturlig forståelse av «gjelder» tilsier at rettigheten aktualiseres i saker som direkte angår barnet. «Angå» er også synonym for «gjelde».79 Som vist i kapittel 3.3.2.3 omfatter «affecting» langt flere tilfeller enn «gjelder». I artikkel 12 nr. 1 står det også «all matters affecting the child» (min utheving), som ytterligere styrker forståelsen av at konvensjonsbestemmelsen er vid. Både ordlydens alminnelige forståelse og ordboken viser altså at lovgivers språklige valg innebærer at terskelen for aktualisering av rettigheten er lavere i artikkel 12 enn i $\S 104$, slik at grunnlovsbestemmelsen er snevrere enn konvensjonsbestemmelsen.

\footnotetext{
76 Dokument 16 (2011-2012) s. 191.

77 1.c.

78 Ordnett.no(a).

79 Ordnett.no(c).
} 
I den norske oversettelsen av konvensjonen står det for øvrig «vedrører». ${ }^{80}$ Både «angå», som er synonymt med «gjelde», og «berøre», som er en oversettelse av «affect», er synonymer for «vedrøre». ${ }^{81}$

Menneskerettighetsutvalget uttaler på side 191 i Dokument 16 (2011-2012) at «gjelder» er brukt for å «tydeliggjøre at barn ikke har rett til å bli hørt eller har rett til medbestemmelse i saker hvor de kan være berørt, men som primært angår andre personer». ${ }^{82}$ Dette er i strid med ordlyden i barnekonvensjonen og den generelle kommentaren, jfr. kapittel 3.3.2.3. Menneskerettighetsutvalget sier riktignok ikke uttrykkelig at det bevisst er valgt er snevrere formulering i grunnlovsbestemmelsen enn i konvensjonsbestemmelsen, men uttalelsen kan likevel forstås slik. ${ }^{83}$ Samtidig uttaler Menneskerettighetsutvalget at «Forslagene ble bl.a. fremmet for å bringe den $\varnothing$ vrige lovgivningen i overensstemmelse med barnekonvensjonen artikkel $12 .{ }^{84} \mathrm{I}$ samme forarbeid vises det for øvrig også til barnelova og den finske grunnloven. ${ }^{85}$

I 2012 kom Grunnlovsspråkutvalget med en rapport om utarbeidelse av språklig oppdaterte tekstversjoner av Grunnloven for begge målformer, Dokument 19 (2011-2012). Grunnlovsspråkutvalget bruker også «gjelder» i sitt forslag til § 104, men begrunner det ikke. ${ }^{86}$

I Grunnlovsforslag 30 (2011-2012) fra 2012 ble det så fremmet to forslag til ny $§ 104$ (1). ${ }^{87}$ Alternativ 1B, som samsvarer med Menneskerettighetsutvalgets forslag, har samme ordlyd som dagens $\S 104 .{ }^{88}$ I alternativ 2B er «gjelder» byttet ut med «berører», ${ }^{89}$ som er en direkte oversettelse av «affect». ${ }^{90}$ Utvalget går ikke inn på forskjellen på betydningen av «gjelder» og «berører», men bemerker at dette er forskjellen på forslagene. ${ }^{91}$

I mai 2014 kom den nevnte Innst. 186 S (2013-2014), innstillingen fra kontroll- og konstitusjonskomiteen om forslaget fremstilt i Grunnlovsforslag 30. Mindretallet innstilte på alternativ 2B. Begrunnelsen var at bestemmelsen da ville samsvare med barnekonvensjonen artikkel 12 .

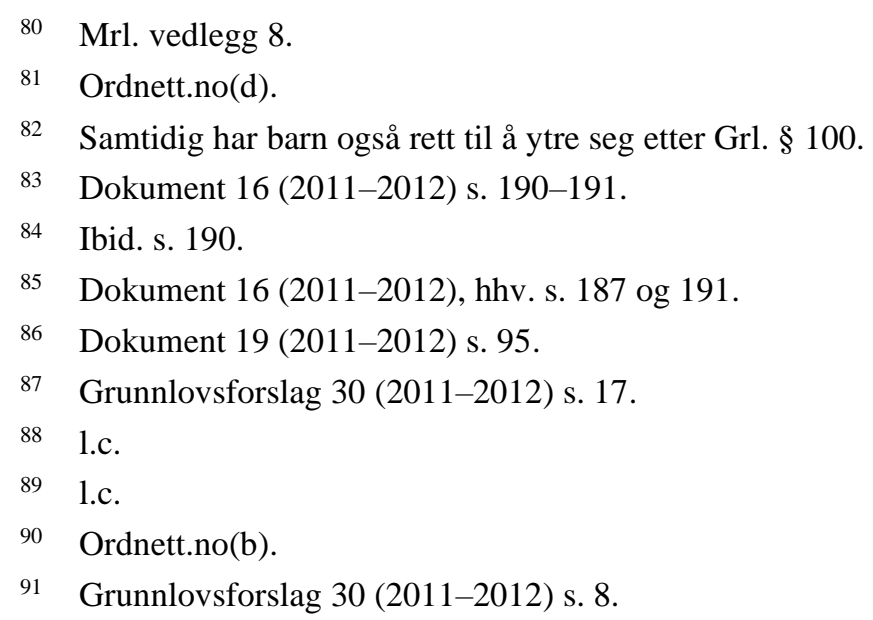


Flertallet innstilte på alternativ 1B, som er den formuleringen vi har i § 104 i dag, og presiserte at «gjelder» skal leses som «angår», og ikke som «berørt». ${ }^{92}$ Flertallet kommenterer ikke direkte forholdet til artikkel 12, men når de uttaler at barn har rett til å bli hørt «i saker som angår dem direkte, til forskjell fra i saker hvor de kan være berørt», og deretter viser til Menneskerettighetsutvalgets uttalelser på side 191 i Dokument 16 (2011-2012), er det tydelig at det igjen aktivt velges en snevrere formulering enn i barnekonvensjonen. ${ }^{93}$

Forarbeidene til $\S 104$ og den generelle kommentaren underbygger altså at grunnlovsbestemmelsen er snevrere enn konvensjonsbestemmelsen. Forarbeidene gir ikke noe klart svar på årsaken til at lovgiver valgte å vedta en grunnlovsbestemmelse om retten til å bli hørt som er snevrere enn barnekonvensjonen, som er signert og ratifisert av Norge.

Høyesterett uttaler i avgjørelsen inntatt i Rt. 2015 s. 155 avsnitt 40 at konvensjonsbestemmelser som tilsvarer Grl. § 104 og som allerede er gjeldende rett etter mrl. § 2, skal danne utgangspunkt for tolkning av grunnlovsbestemmelsene. Høyesterett sier ikke hva som skjer når bestemmelsenes ordlyd ikke samsvarer.

I HR-2016-2171-A skriver Høyesterett i avsnitt 36:

«[Justis- og beredskapsdepartementet] drøfter også betydningen av Grunnloven § 104 og barnekonvensjonen artikkel 12 om barns rett til å bli hørt i spørsmål som gjelder dem selv, og at deres syn skal tillegges vekt i samsvar med deres alder og utvikling.» (min utheving)

Høyesterett gjengir departementets vurdering som at det følger av både konvensjonsbestemmelsen og grunnlovsbestemmelsen at rettigheten gjelder i spørsmål som gjelder barnet. Men det uttrykket departementet faktisk anvender er «vedrører». ${ }^{94}$ «Vedrører» kan som nevnt bety både «angå» og «berøre». Uttrykket departementet anvender i proposisjonen dekker med andre ord begge bestemmelsene. Høyesteretts gjengivelse av departementets uttalelse er unøyaktig, og resultatet kan være at innholdet blir forskjellig.

I kjennelsen inntatt i HR-2016-2314-U avsnitt 16 benyttes «angår» om både Grl. $§ 104$ og barnekonvensjonen artikkel 12. I HR-2017-1996-U avsnitt 14 gjengis ordlyden i Grl. § 104, før Høyesterett uttaler at en «tilsvarende rett» følger av artikkel 12. Heller ikke i disse avgjørelsene

92 Innst. $186 \mathrm{~S}(2013-2014)$ s. 1 og 29-30.

93 Innst. 186 S (2013-2014) s. 29-30.

94 Prop. 112 L (2014-2015) s. 83. 
problematiseres den språklige forskjellen. I HR-2019-1230-A avsnitt 56 uttaler Høyesterett at «born har rett til å bli høyrt i spørsmål som har tyding for dei, jf. Grunnlova $§ 104$ fyrste ledd, FNs barnekonvensjon artikkel 12 og barnelova $\S 31 »$ (min utheving). «Betydning» brukes verken i $\S 104$ eller artikkel $12 .{ }^{95}$ «Viktighet» er synonym for betydning, ${ }^{96}$ som trekker i retning av at det omfatter flere saker enn «gjelder» og «angår», og mer i retning av «berører» og «påvirker». Heller ikke her forholder Høyesterett seg bevisst til språket.

Det er ikke noe subjektivt vilkår i § 104. At Grunnloven ikke stiller subjektive krav til barnet, gjør at grunnlovsteksten på dette punktet er videre enn konvensjonsteksten. Samtidig er det naturlig å forstå det slik at barnet må være i stand til å gjøre seg opp en mening om saken også etter $\S 104$. Dette behandles ikke i forarbeidene, ${ }^{97}$ men i HR-2019-1230-A avsnitt 56 ser det ut til at også Høyesterett forstår grunnlovsbestemmelsen slik: «Dette føresett av borna er i stand til å vurdere spørsmålet på eit sjølvstendig grunnlag.»

\subsubsection{Virkning}

Dersom spørsmålet «gjelder» barnet, har det «rett til å bli hørt». I likhet med konvensjonsbestemmelsen, står det uttrykkelig at det er en rettighet. I artikkel 12 nr. 1 står det riktignok ikke at det er en rett til å bli hørt, men en rett til å «express» sine synspunkter. I artikkel $12 \mathrm{nr}$. 2 står det at barnet skal høres, men det står «opportunity», og ikke «right». En naturlig forståelse av «rett til å bli hørt»er at barnet ikke bare har rett til å uttale seg, men også til at noen skal lytte. Slik er også artikkel 12 nr. 1 naturlig å forstå, jfr. kapittel 3.3.2.4.

Grunnlovsbestemmelsen har ingen formulering som tilsvarer «freely», som nok henger sammen med at bestemmelsen er formulert som en rett til å bli hørt, og ikke til å uttrykke seg.

Rett til informasjon nevnes i likhet med artikkel 12 ikke i $§ 104$. Det nevnes heller ikke i forarbeidene, ${ }^{98}$ og behandles ikke direkte i høyesterettspraksis. Men også her vil informasjon være en forutsetning for å kunne uttale seg, i likhet med konvensjonsbestemmelsen, jfr. kapittel 3.3.2.4.

95 «Betydning» benyttes heller ikke i bl. $§ 31$.

96 Ordnett.no(e).

97 Dokument 16 (2011-2012), Dokument 19 (2011-2012), Grunnlovsforslag 30 (2011-2012), Innst. 186 S (2013-2014).

98 Dokument 16 (2011-2012), Dokument 19 (2011-2012), Grunnlovsforslag 30 (2011-2012), Innst. 186 S (2013-2014). 
Videre har barn rett til at synspunktene «tillegges vekt i overensstemmelse med deres alder og utvikling». Formuleringen er svært lik konvensjonsbestemmelsen. En direkte oversettelse av «maturity» er riktignok «modenhet», men «utvikling» må sies å dekke det samme, når man ser det i sammenheng med barnekomiteens uttalelser om «maturity», se kapittel 3.3.2.4. Det ser ut til at lovgiver også har ment at det innebærer det samme. ${ }^{99}$ Det samme gjør Høyesterett, se for eksempel HR-2017-1996-U avsnitt 15 og Rt. 2014 s. 530 avsnitt 15.

Både ordlyd, forarbeider og rettspraksis tilsier altså at virkningen etter konvensjonsbestemmelsen og Grl. § 104 er den samme.

Avslutningsvis kan det nevnes at $\S 104$ kun er formulert som en rettighetsbestemmelse, til forskjell fra artikkel $12 \mathrm{nr}$. 1, som også er formulert som en pliktbestemmelse for statene.

\subsubsection{Oppsummering og vurdering}

Det er både likheter og forskjeller mellom artikkel 12 nr. 1 og Grl. § 104. To av forskjellene medfører at rettigheten i grunnlovsbestemmelsen er snevrere enn i konvensjonsbestemmelsen.

Rettighetssubjektet i grunnlovsbestemmelsen har både likheter og forskjeller med rettighetssubjektet i konvensjonsbestemmelsen. «Barn» er en direkte oversettelse «child», og begge omfatter personer som ikke har fylt 18 år, jfr. kapittel 3.3.2.1 og 4.1.1. Men forskjellen er at mens grunnlovsbestemmelsen gir en individuell rettighet, gir konvensjonsbestemmelsen både en individuell og en kollektiv rettighet.

Den andre store forskjellen er formuleringen av det objektive vilkåret, som ser ut til å bevisst være formulert snevrere enn i konvensjonsbestemmelsen, med mindre lovgiver har misforstått betydningen av «affect». Samtidig legger rettsanvender til grunn at grunnlovsbestemmelsen og konvensjonsbestemmelsen innebærer det samme. En årsak til at forskjellen ikke påpekes i rettspraksis er nok at ingen av sakene har dreid seg om i hvilke situasjoner rettigheten aktualiseres, slik at det ikke har vært noen grunn til å diskutere forskjellen mellom «affecting» og «gjelder». Høyesterett ville muligens uttalt seg annerledes dersom det var dette saken dreide seg om. En annen årsak kan være at Høyesterett ikke har vært oppmerksom på nyanseforskjellen. En tredje forklaring på at Høyesterett tar lett på ordlydsforskjellene kan være at de legger til grunn at norsk lovgivning forstås i samsvar med forpliktelsene i barnekonvensjonen. Høyesterett diskuterer for øvrig gjennomgående ordlyden i liten grad, både når det gjelder grunnlovsbestemmelsen og konvensjonsbestemmelsen.

99 Innst. 186 S (2013-2014) s. 29. 
Sandberg peker på forskjellen mellom «affecting» og «gjelder», men viser til at dersom problemstillingen skulle komme på spissen, vil den videre rettigheten som følger av artikkel 12 nr. 1 uansett gjelde. ${ }^{100}$ Jeg synes likevel det er interessant at Høyesterett gjennomgående setter likhetstegn ved innholdet i artikkel 12 og $§ 104$, fordi lovgiver aktivt har valgt «gjelder», og presisert at dette ikke skal forstås som «berørt».

En norsk domstol vil neppe nekte barn en videre rettighet, dersom dette skulle komme på spissen. Det finnes også bestemmelser i norsk lovgivning om barns rett til å bli hørt i saker som ikke nødvendigvis gjelder dem direkte, for eksempel pbl. §§ 3-3 (3) og 5-1 (2) første punktum. Samtidig er det klart at ulike formuleringer, både som medfører rettslige ulikheter og som ikke nødvendigvis gjør det, skaper språklig uklarhet, som kan føre til rettsusikkerhet. Dette gjelder spesielt når to generelle bestemmelser er formulert forskjellig, fordi det er naturlig å forvente at de innebærer det samme.

En annen forskjell er at grunnlovsbestemmelsen ikke har et subjektivt vilkår, men dette er det naturlig å innfortolke. Virkningen etter de to bestemmelsene er også formulert litt forskjellig, men innholdsmessig er de like, så det er ikke en rettslig forskjell.

Oppsummeringsvis medfører altså forskjellene i formulering at $§ 104$ er snevrere enn artikkel 12, men det gir seg ikke utslag i høyesterettspraksis. Samtidig kan artikkel 12 gjennomføres i norsk rett på ulike måter, og ikke kun i Grunnloven. Her har lovgiver valgt å gi deler av konvensjonsrettigheten grunnlovs rang ved å grunnlovsfeste en rett til å bli hørt i saker som «gjelder» et enkeltbarn. Resten av rettigheten gjennomføres både i menneskerettsloven, og har derfor semikonstitusjonell rang jfr. mrl. $\S 2$ og 3 , og i alminnelig lovgivning.

\subsection{Barnelovene}

\begin{tabular}{|l|l|l|l|l|}
\hline & Rettighetssubjekt & Pliktsubjekt & Vilkår & Virkning \\
\hline BK art. 12 nr. 1 & «the child» & «States Parties» & $\begin{array}{l}\text { 1) «capable of } \\
\text { forming his or her } \\
\text { own views» }\end{array}$ & $\begin{array}{l}\text { 1) «right to express } \\
\text { those views freely» }\end{array}$ \\
& & $\begin{array}{l}\text { 2) «matters } \\
\text { affecting the child» }\end{array}$ & $\begin{array}{l}\text { 2) «the views of the } \\
\text { child being given } \\
\text { due weight in } \\
\text { accordance with the }\end{array}$ \\
\hline
\end{tabular}

100 Sandberg (2016) s. 95. 


\begin{tabular}{|c|c|c|c|c|}
\hline & & & & $\begin{array}{l}\text { age and maturity of } \\
\text { the child» }\end{array}$ \\
\hline Adl. § 9 (1) & «barnet», «barn» & «[departementet] ${ }^{101}$ & $\begin{array}{l}\text { 1) «har barnet fylt } \\
\text { sju år»: } \\
\text { 1.1) «vedtak om } \\
\text { adopsjon» } \\
\text { 2) «barn som er } \\
\text { yngre enn sju år» } \\
\text { 2.1) «vedtak om } \\
\text { adopsjon» } \\
\text { 2.2) «i stand til å } \\
\text { danne seg egne } \\
\text { synspunkter» }\end{array}$ & $\begin{array}{l}\text { 1) «gis mulighet til } \\
\text { å uttale seg» } \\
\text { 2) «få informasjon } \\
\text { om hva en adopsjon } \\
\text { innebærer» } \\
\text { 3) «[få] veiledning } \\
\text { som er tilpasset } \\
\text { barnets evne til å } \\
\text { forstå } \\
\text { 4) «barnets mening } \\
\text { skal tillegges vekt i } \\
\text { samsvar med dets } \\
\text { alder og modenhet» }\end{array}$ \\
\hline Bbfl. § 17 (1) & $\begin{array}{l}\text { «et barn», «barn», } \\
\text { «barnet» }\end{array}$ & «retten» & $\begin{array}{l}\text { 1) «barn som er fylt } \\
\text { sju år»: } \\
\text { 1.1) «avgjør et krav } \\
\text { om } \\
\text { tvangsfullbyrding } \\
\text { (...) eller begjæring } \\
\text { om tilbakelevering } \\
\text { av barn» } \\
\text { 2) «yngre barn»: } \\
\text { 2.1) «avgjør et krav } \\
\text { om } \\
\text { tvangsfullbyrding } \\
\text { (...) eller begjæring } \\
\text { om tilbakelevering } \\
\text { av barn» } \\
\text { 2.2) «i stand til å } \\
\text { danne seg egne } \\
\text { synspunkter» } \\
\text { Uavhengig av } \\
\text { barnets alder er det } \\
\text { også et vilkår at det } \\
\text { «ikke er umulig». }\end{array}$ & $\begin{array}{l}\text { 1) «informeres» } \\
\text { 2) «gis anledning til } \\
\text { å uttale seg» } \\
\text { 3) «barnets mening } \\
\text { skal tillegges vekt i } \\
\text { samsvar med } \\
\text { barnets alder og } \\
\text { modenhet» }\end{array}$ \\
\hline
\end{tabular}

101 Jfr. adl. § 3. 


\begin{tabular}{|c|c|c|c|c|}
\hline $\begin{array}{l}\text { Bhl. § } 1 \text { (2) tredje } \\
\text { pkt. }\end{array}$ & «[barna $] »{ }^{102}, \ll$ de» & «[barnehagen] $»^{103}$ & & $\begin{array}{l}\text { «rett til } \\
\text { medvirkning } \\
\text { tilpasset alder og } \\
\text { forutsetninger» }\end{array}$ \\
\hline Bhl. § 3 & «barn» & «[barnehagen] $]{ }^{104}$ & $\begin{array}{l}\text { 1) «i barnehagen» } \\
\text { 2) «barnehagens } \\
\text { daglige } \\
\text { virksomhet» }\end{array}$ & $\begin{array}{l}\text { 1) «rett til å gi } \\
\text { uttrykk for sitt syn» } \\
\text { 2) «skal jevnlig få } \\
\text { mulighet til aktiv } \\
\text { deltakelse i } \\
\text { planlegging og } \\
\text { vurdering» } \\
\text { 3) «barnets } \\
\text { synspunkter skal } \\
\text { tillegges vekt i } \\
\text { samsvar med dets } \\
\text { alder og modenhet» }\end{array}$ \\
\hline Bl. § 31 (1) & «barnet» & $\begin{array}{l}\text { «foreldra», «andre } \\
\text { som barnet bur hos } \\
\text { eller som har med } \\
\text { barnet å gjere» }\end{array}$ & $\begin{array}{l}\text { 1) «avgjerd om } \\
\text { personlege forhold } \\
\text { for barnet» } \\
\text { 2) «i stand til å } \\
\text { danne seg eigne } \\
\text { synspunkt på det } \\
\text { saka dreiar seg om» }\end{array}$ & $\begin{array}{l}\text { 1) «skal foreldra } \\
\text { høyre kva barnet } \\
\text { har å seie» } \\
\text { 2) «dei skal leggje } \\
\text { vekt på det barnet } \\
\text { meiner alt etter kor } \\
\text { gammalt og modent } \\
\text { barnet er» }\end{array}$ \\
\hline BI. § 31 (2) & $\begin{array}{l}\text { «eit barn», «barn», } \\
\text { «barnet» }\end{array}$ & $\begin{array}{l}\text { «foreldra», «andre } \\
\text { som barnet bur hos } \\
\text { eller som har med } \\
\text { barnet å gjere» }{ }^{105}\end{array}$ & $\begin{array}{l}\text { 1) «eit barn som er } \\
\text { fylt sju år»: } \\
\text { 1.1) «avgjerd om } \\
\text { personlege forhold } \\
\text { for barnet, mellom } \\
\text { anna om foreldre- } \\
\text { ansvaret, kvar } \\
\text { barnet skal bu fast } \\
\text { og samvær» } \\
\text { 2) «yngre barn»: } \\
\text { 2.1) «avgjerd om } \\
\text { personlege forhold } \\
\text { for barnet mellom }\end{array}$ & $\begin{array}{l}\text { 1) «skal få } \\
\text { informasjon» og } \\
\text { 2) «høve til å seie } \\
\text { meininga si» } \\
\text { 3) «meininga til } \\
\text { barnet skal bli vekt- } \\
\text { lagt etter alder og } \\
\text { modning» } \\
\text { 4) «når barnet er } 12 \\
\text { år, skal det leggjast }\end{array}$ \\
\hline
\end{tabular}

102 «Barna» står i bhl. § 1 (2) første pkt. «De» i tredje pkt. peker tilbake på «barna».

103 Jfr. bhl. § 1 (1) første pkt.

104 Jfr. lovens system.

105 Jfr. bl. § $31(1)$. 


\begin{tabular}{|c|c|c|c|c|}
\hline & & & $\begin{array}{l}\text { anna om foreldre- } \\
\text { ansvaret, kvar } \\
\text { barnet skal bu fast } \\
\text { og samvær» } \\
\text { 2.2) «i stand til å } \\
\text { danne seg eigne } \\
\text { synspunkt» }\end{array}$ & $\begin{array}{l}\text { stor vekt på kva } \\
\text { barnet meiner» }\end{array}$ \\
\hline $\begin{array}{l}\text { Bvl. § 1-6 første til } \\
\text { tredje pkt. }\end{array}$ & $\begin{array}{l}\text { «alle barn», } \\
\text { «barnet» }\end{array}$ & $\begin{array}{l}\text { «[alle instanser som } \\
\text { har oppgaver etter } \\
\text { barnevernloven]» }\end{array}$ & $\begin{array}{l}\text { 1) «forhold som } \\
\text { vedrører barnet } \\
\text { etter denne loven» } \\
\text { 2) «i stand til å } \\
\text { danne seg egne } \\
\text { synspunkter» }\end{array}$ & $\begin{array}{l}\text { 1) «rett til å med- } \\
\text { virke» } \\
\text { 2) «skal få } \\
\text { tilstrekkelig og til- } \\
\text { passet } \\
\text { informasjon» } \\
\text { 3) «rett til fritt å gi } \\
\text { uttrykk for sine } \\
\text { synspunkter» } \\
\text { 4) «skal bli lyttet } \\
\text { til» } \\
\text { 5) «synspunkter } \\
\text { skal vektlegges i } \\
\text { samsvar med } \\
\text { barnets alder og } \\
\text { modenhet» }\end{array}$ \\
\hline Bvl. § 6-3 (1) & $\begin{array}{l}\text { «et barn», «barn», } \\
\text { «ham eller henne», } \\
\text { «barnet» }\end{array}$ & $\begin{array}{l}\text { «[alle instanser som } \\
\text { har oppgaver etter } \\
\text { barnevernloven]» }{ }^{107}\end{array}$ & $\begin{array}{l}\text { 1) «et barn som har } \\
\text { fylt } 7 \text { år»: } \\
\text { 1.1) «avgjørelse i } \\
\text { sak som berører } \\
\text { ham eller henne» } \\
\text { 2) «yngre barn»: } \\
\text { 2.1) «avgjørelse i } \\
\text { sak som berører } \\
\text { ham eller henne» } \\
\text { 2.2) «i stand til å } \\
\text { danne seg egne } \\
\text { synspunkter» }\end{array}$ & $\begin{array}{l}\text { 1) «skal } \\
\text { informeres» og } \\
\text { 2) «gis anledning } \\
\text { til å uttale seg» } \\
\text { 2) «barnets mening } \\
\text { skal tillegges vekt i } \\
\text { samsvar med } \\
\text { barnets alder og } \\
\text { modenhet» }\end{array}$ \\
\hline
\end{tabular}

106 Prop. 169 L (2016-2017) s. 44.

107 1.c. 


\begin{tabular}{|l|l|l|l|l|}
\hline $\begin{array}{l}\text { Oppll. § 1-1 (6) } \\
\text { annet pkt. }\end{array}$ & $\begin{array}{l}\text { «[elevane }] »,{ }^{108} \\
\text { «dei» }\end{array}$ & $\begin{array}{l}\text { «skole og lærebe- } \\
\text { drift }] » 109\end{array}$ & $\begin{array}{l}\text { «skal ha medansvar } \\
\text { og rett til medverk- } \\
\text { nad» }\end{array}$ \\
\hline
\end{tabular}

\subsubsection{Rettighetssubjekt}

Både barnelova og barnevernloven formulerer rettighetssubjektet som forskjellige varianter av «barn». Ingen av lovene har noen definisjon av «barn», men en naturlig forståelse tilsier at det er personer som ikke har fylt 18 år. Bvl. § 1-3 (1) og bl. § 33 opererer også med et skille ved 18 år. Det samme gjør forarbeidene til de to lovene. ${ }^{110}$ Hvem som er «barn» diskuteres ikke i rettspraksis. Man kan etter dette legge til grunn at «barn» i barnelova og barnevernloven og «child» i barnekonvensjonen omfatter samme personer.

Også i adl. § 9 (1), bbfl. § 17 (1), bhl. §§ 1 (2) og 3 og bvl. § 6-3 (1) er rettighetssubjektet varianter av «barn».

I oppll. § 1-1 (6) annet punktum er rettighetssubjektet «elevane». En naturlig forståelse tilsier at det ikke er alderen som er avgjørende, men rollen som skoleelev. Loven gjelder også videregående skoler, jfr. § 1-2 (1), hvor elevene kan være eldre enn 18 år. De aller fleste elever har likevel ikke fylt 18. Alder diskuteres ikke i forarbeidene i forbindelse med dette. ${ }^{111}$ Det er ingen høyesterettsavgjørelser om oppll. § 1-1, og underrettsavgjørelsene dreier seg ikke om retten til å bli hørt.

Felles for bestemmelsene er at formuleringene ikke er klare på om rettigheten er individuell, kollektiv eller begge deler. Samtidig fremgår dette ofte av rettsområdet. Jeg går ikke nærmere inn på dette, ettersom bestemmelsene i barnelovene gjelder på ulike rettsområder og situasjoner, hvor det varierer om det er naturlig å ha en individuell eller kollektiv rettighet. Det har derfor lite for seg å sammenlikne med artikkel 12 .

\subsubsection{Vilkår}

Både i barnelovene og i annen lovgivning vil formuleringer som tilsvarer «all matters affecting the child» i tillegg til å kunne leses som vilkår, også kunne leses som del av rettighetssubjektet

\footnotetext{
108 «Elevane» står i oppll. § 1-1 (6) første pkt. «Dei» i annet pkt. viser tilbake til «elevane».

109 Jfr. oppll. § 1-1 (1) og (7).

110 For barnelova, se f.eks. NOU 1977: 35 s. 9, Ot.prp. nr. 62 (1979-1980) s. 5 og Innst.O. nr. 30 (1980-1981) s. 8. For barnevernloven, se Ot.prp. nr. 44 (1991-1992) s. 5 og Prop. 43 L (2011-2012).

111 Ot.prp. nr. 46 (2007-2008), Innst.O. nr. 22 (2008-2009).
} 
eller virkningen. Det kan derfor fremstå som noe kunstig å kategorisere dem som vilkår. Et eksempel på førstnevnte er «mindreårige parter» (min utheving) i fvl. § 17 (1). Et eksempel på sistnevnte er «skal foreldra høyre kva barnet har å seie før dei tek avgjerd om personlege forhold for barnet» (min utheving) i bl. $\S 31$ (1). Fordi utgangspunktet for sammenlikningen er artikkel 12, og barnekomiteen har uttalt at «matters affecting the child» er et vilkår, kategoriseres tilsvarende formuleringer som objektive vilkår både i dette kapitlet og i 4.3 .2 om vilkår i annen lovgivning.

Både for barnelovene og annen lovgivning er vilkår som tilsvarer det objektive vilkåret $\mathrm{i}$ artikkel 12 snevrere enn konvensjonsbestemmelsens, fordi det er «matters» som gjelder det rettsområdet loven regulerer. Dette er ikke nødvendigvis i strid med konvensjonsbestemmelsen, som gjelder «all matters». Jeg kommer derfor ikke til å sammenlikne dette vilkåret i de forskjellige bestemmelsene med artikkel 12 .

Fremstillingen og sammenlikningen av vilkårene i barnelovene er delt i tre: 1) bestemmelser som har to vilkår tilsvarende vilkårene i artikkel $12 \mathrm{nr} .1$; 2) bestemmelser som har to vilkår tilsvarende vilkårene i artikkel 12 nr. 1, men hvor vilkårene varierer med barnets alder; 3) bestemmelser som kun har objektive vilkår.

\subsubsection{To vilkår tilsvarende vilkårene i artikkel 12 nr. 1: bl. § 31 (1) og bvl. § 1-6 forste til tredje punktum}

B1. § 31 (1) og bvl. § 1-6 har begge to vilkår som tilsvarer de to vilkårene i artikkel 12.

Det objektive vilkåret i bl. $\S 31$ (1) er at det er «avgjerd om personlege forhold for barnet». Det subjektive vilkåret er at barnet må være «i stand til å danne seg eigne synspunkt på det saka dreiar seg om». Dette er en direkte oversettelse av konvensjonsbestemmelsens subjektive vilkår, bortsett fra «på det saka dreiar seg om». Men som vist i kapittel 3.3.2.3 gjelder også artikkel 12 synspunkter på det aktuelle spørsmålet. Formuleringen kommenteres så vidt i forarbeidene, hvor det også vises til barnekonvensjonen. ${ }^{112}$ Men det står ikke noe om bakgrunnen for at «på det saka dreiar seg om» er inntatt. ${ }^{113}$ Det er derfor vanskelig å si hvorfor det er presisert at det er synspunkter på saken. Det kan være fordi dette er den naturlige for-ståelsen av artikkel 12 . Vilkåret diskuteres heller ikke i rettspraksis fra siste endring trådte i kraft i 2014. Det kan uansett legges til grunn at denne forskjellen mellom artikkel $12 \mathrm{nr} .1 \mathrm{og}$ bl. $§ 31$ (1) ikke innebærer noen innholdsmessig forskjell.

\footnotetext{
112 Innst.O. nr. 96 (2002-2003) s. 12.

113 Ot.prp. nr. 29 (2002-2003), Innst.O. nr. 96 (2002-2003).
} 
For $\emptyset$ vrig nevnes barnekonvensjonen en rekke ganger i forarbeidene til de siste endringene i $\S 31 .{ }^{114}$ I tidligere forarbeider vises det både til barnekonvensjonen og til andre lands lovgivning. ${ }^{115}$

De to vilkårene i bvl. § 1-6 er at barnet er «i stand til å danne seg egne synspunkter» og at det er «forhold som vedrører barnet etter denne loven». Førstnevnte er en ordrett oversettelse av det subjektive vilkåret i artikkel 12. Det er naturlig å forstå dette som synspunkter på saken, jfr. kapittel 3.3.2.3. Denne forståelsen underbygges også av formuleringen «etter denne loven» $\mathrm{i}$ § 1-6 første punktum. Det står ikke noe om dette i forarbeidene. ${ }^{116}$ Det er ingen høyesterettsavgjørelser om bestemmelsen, og ingen av lagmannsrettsavgjørelsene diskuterer vilkårene. Men i LB-2019-67035 nevnes helt kort at barn har rett til medvirkning i «alle forhold som vedrører barnet etter barnevernloven». Se mer om «vedrører» i kapittel 4.1.3.

Det objektive vilkåret diskuteres i utgangspunktet ikke her, men det er likevel verdt å nevne at formuleringen av vilkåret i § 1-6 er svært lik formuleringen i barnekonvensjonen, med unntak av «etter denne loven». I forarbeidene henvises det også til artikkel 12. ${ }^{117}$ Da er det interessant at det står «vedrører» i $§ 1-6$, som benyttes i den norske oversettelsen av barnekonvensjonen. «Vedrøre» brukes også i forarbeidene til § 1-6 når artikkel 12 omtales. ${ }^{118}$ Når så «vedrører» benyttes i lovteksten, trekker det i retning av at det skal forstås på samme måte som «affect» $\mathrm{i}$ artikkel 12. Det står ellers ikke noe nærmere om valget av «vedrører» i forarbeidene. ${ }^{119} \mathrm{Be}-$ tydningen av «vedrører» diskuteres ikke i lagmannsrettspraksis. Til forskjell fra «affect» $\mathrm{i}$ artikkel 12 og «gjelder» i Grunnloven, er riktignok ikke «vedrører» avgjørende for i hvilke saker barnet har rett til å bli hørt, jfr. «etter denne loven».

I april 2019 kom forslaget til ny barnevernslov. ${ }^{120}$ Barnevernlovutvalgets innstilling er allerede delvis fulgt opp gjennom lovendringer som trådte i kraft i 2018, og det er i sammenheng med dette at $\S 1-6$ ble vedtatt. ${ }^{121}$ Lovendringene medførte at loven ble en rettighetslov for barn, og

\footnotetext{
114 Ot.prp. nr. 29 (2002-2003) s. 58 og 60, Prop. 85 L (2012-2013), f.eks. s. 16, 17 og 37-38, Innst. 151 L (20172018), se f.eks. s. 6.

115 Ot.prp. nr. 29 (2002-2003), f.eks. s. 58. Se også NOU 1977: 35 s. 13-16.

116 Prop. 169 L (2016-2017), Innst. 151 L (2017-2018).

117 Prop. 169 L (2016-2017) s. 17. Se også NOU 2016: 16 s. 58 om ny barnevernslov. I NOUen vises det også til lovgivning om barnevern $\mathrm{i}$ andre land.

118 Prop. 169 L (2016-2017) s. 39.

119 Prop. 169 L (2016-2017), Innst. 151 L (2017-2018).

120 BFD (2019).

121 BLD (2019) s. 211.
} 
barnets medvirkning ble styrket. ${ }^{122}$ I lovforslaget blir någjeldende $\S 1-6$ til $\S 1-5 .{ }^{123}$ Den foreslåtte bestemmelsen har samme ordlyd som $\S 1-6$, men «synspunkter» er byttet ut med «mening», som kan være et forsøk på å gjøre språket klarere. ${ }^{124}$ Bvl. § 6-3 (1) foreslås opphevet. ${ }^{125}$ I Prop. 169 L (2016-2017) side 41 og BLD (2019) s. 46 sier utvalget at det ikke ønsker å videreføre aldersgrensen på sju år i § 6-3 (1). Begrunnelsen er at det må foretas en konkret vurdering av hvorvidt barnet er i stand til å danne og formidle egne synspunkter, at det ikke er noen aldersgrense $\mathrm{i}$ artikkel 12, og at barnekomiteen fraråder det. ${ }^{126}$ En tilsvarende aldersgrense finner vi i bl. $\S 31$ (2), se mer i neste kapittel.

\subsubsection{To vilkår som tilsvarer artikkel $12 \mathrm{nr} .1$, men de er knyttet til alder:}

bl. $\$ 31$ (2)

B1. § 31 (2) har tilsvarende vilkår som bestemmelsene med to vilkår, men har i tillegg en aldersgrense på sju år, som innebærer at det er færre vilkår for barn som har fylt sju enn for yngre barn.

For «yngre barn» enn sju er det to vilkår. Det subjektive vilkåret er at barnet må være «i stand til å danne seg eigne synspunkt», som er en direkte oversettelse av artikkel $12 \mathrm{nr}$. 1. I likhet med konvensjonsbestemmelsen er det naturlig å forstå dette som synspunkter på saken. Også forarbeidene trekker i denne retningen. ${ }^{127}$ Høyesteretts uttalelser i HR-2019-1230-A avsnitt 56 kan tolkes som at også rettsanvender forstår bestemmelsen slik. ${ }^{128}$

Det objektive vilkåret er at det gjelder «avgjerd om personlege forhold for barnet, mellom anna om foreldreansvaret, kvar barnet skal bu fast og samvær». Dette er samme vilkår som i $\S 31$ (1), men med eksempler på «personlege forhold». Eksemplene ble inntatt i 2014, og en begrunnelse var at det ville $\emptyset$ ke bevisstheten om at barnet skal få komme med synspunkter på alle forhold som «vedrører» det, som følger av artikkel $12 .{ }^{129}$

Når barnet har fylt sju, gjelder kun det objektive vilkåret. Dette innebærer en utvidelse av rettigheten for disse barna. En naturlig forståelse av sjuårsgrensen er at barn som har fylt sju alltid antas å være i stand til å danne seg egne synspunkter på saken.

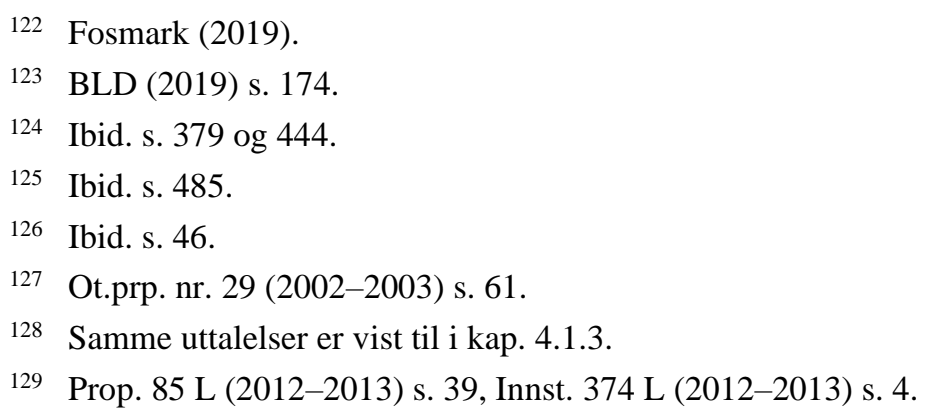


Aldersgrenser er i utgangspunktet verken i tråd med konvensjonsbestemmelsen eller den generelle kommentaren, se kapittel 3.3.2.3. I Ot.prp. nr. 29 (2002-2003) side 61 påpekes det at det var foreslått en sjuårsgrense i adopsjonsloven og barnevernloven, og at det var ønskelig at de tre bestemmelsene var like. I Prop. 85 L (2012-2013) side 86 uttales det at barn som har fylt sju har en ubetinget rett til å uttale seg når det skal tas avgjørelser om personlige forhold for barnet. ${ }^{130}$ Flere steder i proposisjonen presiseres det at også yngre barn har rett til å bli hørt, se for eksempel side 35. På side 37-38 uttaler departementet at regelverket allerede oppfylte artikkel 12, men at de foreslåtte endringene ville bidra til bedre oppfyllelse, og var i tråd med generelle kommentarer og merknader til Norges rapporter til barnekomitéen.

Presiseringen om yngre barn var blant endringene som kom inn fra 2014. ${ }^{131}$ Departementet uttaler i Prop. 85 L (2012-2013) på side 38 at rettspraksis viste et behov for en slik presisering, fordi de yngste barna ikke ble hørt i tilstrekkelig grad etter dagjeldende regelverk. Sjuårsgrensen ble ikke fjernet i forbindelse med siste endring, fordi departementet mente grensen har vært viktig for å sikre barns rett til å bli hørt fra de er sju, jfr. uttalelsene på side 39. Da er det spesielt interessant at sjuårsgrensen er foreslått fjernet i ny barnevernslov.

Departementets uttalelser underbygger forståelsen av at lovgiver har ment å utvide rettigheten for barn som har fylt sju, uten å begrense rettigheten for yngre barn. Da er det ikke egentlig en aldersgrense, og derfor ikke i strid med konvensjonsbestemmelsen. Rettsanvender ser også ut til å forstå sjuårsgrensen slik, jfr. Høyesteretts uttalelse i HR-2019-1230-A avsnitt 56: «Det er ikkje noka aldersgrense for retten til å uttale seg.» Slike aldersgrenser blir derfor videre omtalt som relative alders-grenser.

Bvl. § 6-3 (1) er svært lik bl. § 31 (2). Det står også i Ot.prp. nr. 44 (1991-1992) side 117 at bestemmelsen bygger på bl. §31. Også adl. § 9 (1) og bbfl. § 17 (1) oppstiller to vilkår for barn som ikke har fylt sju, og kun det objektive vilkåret for barn som har fylt sju. Etter barnebortføringsloven er det i tillegg et vilkår at det ikke er «umulig» å gi barnet mulighet til å uttale seg, som er naturlig ettersom det kan være vanskelig å komme i kontakt med bortførte barn.

\subsubsection{Kun objektive vilkår: oppll. § 1-1 (6) annet punktum}

I oppll. § 1-1 (6) annet punktum er det ingen uttalte vilkår, men lovens system tilsier at man må være elev ved den aktuelle skolen, som er et objektivt vilkår. Vilkår er ikke tema i lovforarbeidene, ${ }^{132}$ og det er ingen relevant rettspraksis.

\footnotetext{
130 Se også Prop. 85 L (2012-2013) s. 17 og Ot.prp. nr. 29 (2002-2003) s. 61.

131 Lovvedtak 81 (2012-2013).

132 Ot.prp. nr. 46 (2007-2008), Innst.O. nr. 22 (2008-2009).
} 
I Ot.prp. nr. 46 (2007-2008) side 33 uttales det for øvrig at «Barn og unges rett til medvirkning er også nedfelt i FNs barnekonvensjon artikkel 12 nr. 1». Det ser altså ut til at det legges til grunn at bestemmelsen er i tråd med artikkel 12. Det vises for $\varnothing v$ vrig også til lovgivning i andre nordiske land. ${ }^{133}$

Heller ikke bhl. § 1 har uttalte vilkår. Bhl. § 3 har to objektive vilkår.

\subsubsection{Virkning}

Virkningen kan organiseres i disse kategoriene: 1) bestemmelser med todelt virkning i likhet med artikkel $12 \mathrm{nr} .1$; 2) bestemmelser med todelt virkning i likhet med artikkel $12 \mathrm{nr} .1$, men som også nevner informasjon; 3) andre virkninger.

\subsubsection{Virkning som tilsvarer artikkel 12 nr. 1: bl. $\$ 31$ (1)}

I bl. $\S 31$ (1) står det at foreldrene skal «høyre kva barnet har å seie», som tilsvarer konvensjonens «right to express»; for at foreldrene skal kunne høre barnet, må barnet få uttrykke seg. «Høyre» tilsvarer også «to be heard» i artikkel 12 nr. 2. Bestemmelsen dreier seg altså om foreldrenes plikter. I Prop. 85 L (2012-2013) side 35 bemerkes det også at det er en pliktbestemmelse, men det begrunnes ikke. Det diskuteres heller ikke i høyesterettspraksis etter siste endring i 2014. Samtidig er bestemmelsens tittel «Rett for barnet til å vere med på avgjerd».

«Freely» nevnes ikke, men dette er naturlig sett i sammenheng med resten av ordlyden.

Vektingen i $§ 31$ (1) er en direkte oversettelse av konvensjonsbestemmelsen. I 2004 ble formuleringen «alt etter kor gammalt og modent barnet er» lagt til for at bestemmelsen skulle være mer i samsvar med ordlyden i artikkel $12 \mathrm{nr} .1 .^{134}$

I desember 2018 nedsatte regjeringen et utvalg som skal gjennomgå barneloven og legge frem forslag til ny barnelov. ${ }^{135}$ Utvalget skal blant annet gjennomgå aldersgrenser knyttet til retten til å bli hørt. ${ }^{136}$

I bhl. § 3 er formuleringen av virkningen en direkte oversettelse av konvensjonsbestemmelsen.

\footnotetext{
133 Ot.prp. nr. 46 (2007-2008) s. 12.

134 Ot.prp. nr. 29 (2002-2003) s. 81.

135 BFD (2018a).

136 BFD (2018b) s. 3.
} 


\subsubsection{Virkning som tilsvarer artikkel $12 \mathrm{nr} .1$, men også nevner informasjon:}

\section{bl. § 31 (2) og bvl. § 1-6 første til tredje punktum}

Bl. § 31 (2) og bvl. § 1-6 første til tredje punktum har todelt virkning i likhet med artikkel 12 nr. 1, men nevner også informasjon. Samtidig må rett til informasjon innfortolkes i artikkel 12, jfr. kapittel 3.3.2.4.

Formuleringen av virkningen i bl. § 31 (2) skiller seg fra § 31 (1) blant annet ved at informasjon nevnes; barnet «skal få informasjon og høve til å seie meininga si». Rett til informasjon kom inn i § 31 (2) i 2014, og begrunnelsen er den samme i forarbeidene som i den generelle kommentaren, selv om kommentaren ikke nevnes. ${ }^{137}$

«Høve» betyr anledning og mulighet, ${ }^{138}$ som er en direkte oversettelse av «opportunity» i artikkel 12 nr. 2. Det står altså ikke uttrykkelig at det er en rettighet, i likhet med § 31 (1), men til forskjell fra første ledd er likevel rettighetssubjektet i fokus. Denne forskjellen diskuteres verken i forarbeider ${ }^{139}$ eller høyesterettspraksis etter siste endring. Bl. § 31 får altså i likhet med artikkel 12 frem at det både er en rettighet for barn og en plikt for foreldre og andre. ${ }^{140}$ «Seie meininga si» tilsvarer «express those views». Det står ikke at barnet fritt skal få si sin mening, men dette uttales i Ot.prp. nr. 29 (2002-2003) side 63. Det diskuteres ikke i høyesterettspraksis etter siste endring.

Vektingen i § 31 (2) er en direkte oversettelse av artikkel 12 nr. 1, men i tillegg står det at «når barnet er 12 år, skal det leggjast stor vekt på kva barnet meiner». En naturlig forståelse av dette er at når barnet har fylt 12 er det ikke behov for å vurdere vekten ut fra barnets alder og modenhet. Her skiller $§ 31$ (2) skiller seg både fra første ledd, fra artikkel 12 og fra de andre norske bestemmelsene, også bvl. § 6-3 (1) og bbfl. § 17 (1), som er basert på bl. § 31. ${ }^{141}$ Mellom 1981 og 2004 sa bestemmelsen at når barnet har fylt 12 år skulle det få si sin mening, og at det skulle legges stor vekt på barnets mening. ${ }^{142} \mathrm{Da}$ aldersgrensen ble endret til sju år i 2004, ønsket departementet å beholde 12-årsgrensen knyttet til vektingen, men begrunnet det ikke nærmere. ${ }^{143}$ Aldersgrensen er i utgangspunktet ikke i tråd med barnekonvensjonen og barnekomiteens uttalelser, jfr. kapittel 3.3.2.3. Samtidig kan aldergrensen ses som en styrking av retten for barn som har fylt 12, på samme måte som den nevnte sjuårsgrensen.

\footnotetext{
137 Prop. 85 L (2012-2013) s. 36.

138 Ordnett.no(f).

139 Prop. 85 L (2012-2013).

140 Det uttales også i forarbeidene, se f.eks. NOU 2008: 9 s. 17 og Prop. 85 L (2012-2013) s. 86.

141 Ot.prp. nr. 44 (1991-1992) s. 117, Ot.prp. nr. 52 (1987-1988) s. 21.

142 Ot.prp. nr. 29 (2002-2003) s. 57.

143 Ibid. s. 61.
} 
I bvl. § 1-6 første punktum står det at barnet har «rett til å medvirke». Bestemmelsen er altså formulert som en rettighetsbestemmelse. «Medvirke» benyttes ikke i artikkel 12, men benyttes ofte når rettigheten omtales. ${ }^{144}$ En naturlig forståelse av «medvirkning» tilsier en større grad av aktivitet sammenliknet med å bli hørt og at synspunktene skal vektlegges. Synonymer for «medvirkning» er blant annet «delaktighet» og «bidrag». ${ }^{145}$

I forarbeidene vises det til definisjonen av «medvirkning» i § 3 i forskrift 1. juni 2014 om medvirkning og tillitsperson (medvirkningsforskriften). ${ }^{146}$ Forskriftsbestemmelsens ordlyd er en kombinasjon av formuleringen i artikkel $12 \mathrm{nr} .1 \mathrm{og}$ uttalelsene i den generelle kommentaren. I Prop. 169 L (2016-2017) side 43 utdyper barne- og likestillingsdepartementet hva det mener med «medvirkning», nemlig det samme som står i medvirkningsforskriften $\S 3$. Deretter viser departementet til forskriftsbestemmelsen. Til slutt uttaler departementet at det «legger til grunn at retten til medvirkning inneholder det samme som 'retten til å bli hørt' i FNs barnekonvensjon artikkel 12 og § 104». Denne setningen gjentas på side 5 i Innst. 151 L (2017-2018). Dette er interessant ettersom ordlyden i § 1-6 er likere artikkel 12 enn $\S 104$. Det tyder på at lovgiver enten ikke har et bevisst forhold de språklige forskjellene, eller legger til grunn at norsk lovgivning er i samsvar med konvensjonsbestemmelsen.

I bestemmelsens annet punktum står det at barnet «skal få tilstrekkelig og tilpasset informasjon», og «har rett til fritt å gi uttrykk for sine synspunkter». Sistnevnte er en direkte oversettelse av artikkel 12 nr. 1. I Prop. 169 L (2016-2017) side 44 uttaler utvalget at dette «betyr mer enn at barnet har rett til å snakke; barnet kan uttrykke seg både verbalt og ikke-verbalt», slik også barnekomiteen har uttalt i den generelle kommentaren, se kapittel 3.3.2.3 og 3.3.2.4. Med «fritt» skiller $§ 1-6$ seg fra de andre bestemmelsene.

I tredje punktum står det at barnet «skal bli lyttet til», som vi ikke finner i artikkel $12 \mathrm{nr} .1$, men som tilsvarer «to be heard» i artikkel 12 nr. 2. Samtidig står det i artikkel 12 nr. 1 at barnet skal få uttrykke seg fritt og at synspunktene skal vektlegges, som forutsetter at barnet blir lyttet til. I tredje punktum beskrives også vektingen, som er en direkte oversettelse av artikkel 12 nr. 1 .

I lagmannsrettsavgjørelsene går ikke lagmannsretten nærmere inn i ordlyden i bestemmelsen, men slår gjerne fast at den innebærer en rett til å bli hørt, en rett til medvirkning og/eller en rett til å uttale seg, gjerne i sammenheng med bvl. § 6-3, Grl. § 104 og barnekonvensjonen artikkel

144 Se også tittelen på bl. § 31, «Rett for barnet til å være med på avgjerd».

145 Ordnett.no(g).

146 Innst. 151 L (2017-2018) s. 5, Prop. 169 L (2016-2017) s. 41 og 43. 
12. Se for eksempel LB-2019-67035 og LB-2019-53890. I LG-2018-55392 og LF-2017152073 nevnes disse bestemmelsene også i forbindelse med vektingen. Lagmannsrettene ser altså ut til å legge til grunn at barnekonvensjonen artikkel 12, Grl. § 104 (1), bl. § 31 og de to bestemmelsene i barnevernloven innebærer det samme. I saker hvor det nærmere innholdet i $\S$ 1-6 gjengis av lagmannsretten, benyttes samme termer som i bestemmelsen. ${ }^{147}$ I LH-201861825-2 benyttes riktignok «gjelder» og ikke «vedrører», men dette har nok liten betydning når det gjelder $\S 1-6$, jfr. bestemmelsens formulering «etter denne loven». Ut over dette er det lite å hente fra rettspraksis om hvordan rettsanvender forstår $\S 1-6$.

Også adl. § 9 (1), bbfl. § 17 (1) og bvl. § 6-3 (1) har todelt virkning tilsvarende artikkel 12, og nevner i tillegg informasjon. Bvl. § 6-3 (1) er til forskjell fra bvl. § 1-6 formulert som en pliktbestemmelse.

\subsubsection{Andre virkninger: oppll. § 1-1 (6) annet punktum}

I oppll. § 1-1 (6) annet punktum står det at «[elevane] skal ha medansvar og rett til medverknad». «Medvirkning» brukes også i bvl. § 1-6 og bhl. § 1. I Ot.prp. nr. 46 (2007-2008) side 33 vises det til barnekonvensjonen artikkel 12 nr. 1, men det står ikke noe nærmere om formuleringen av virkningen. Det står heller ikke hva som menes med «medverknad», og det vises ikke til medvirkningsforskriften $\S 3$. Det er som nevnt ingen relevant rettspraksis.

En formulering tilsvarende «freely» er ikke inntatt i § 1-1, men det henger nok sammen med at virkningen er en rett til «medvirkning», og ikke for eksempel å uttrykke seg. Det står heller ingenting om vekting.

Videre står det at elevene har «medansvar». I Ot.prp. nr. 46 (2007-2008) side 33 uttales det at medansvar «innebærer at skolen og lærebedriften skal legge til rette for at de skal få erfaring med ulike former for ansvar, deltagelse og medvirkning i demokratiske prosesser både i det daglige arbeidet og ved deltagelse i representative organer». ${ }^{148}$

Bhl. $§ 1$ sier ingenting om vekting, i likhet med opplæringslova. Men formuleringen av virkningen, «skal ha rett til medvirkning tilpasset alder og forutsetninger», har likhetstrekk med vektingen i andre bestemmelser. En forskjell er at det står «forutsetninger» og ikke «modenhet».

\subsubsection{Oppsummering og vurdering}

147 Se f.eks. LB-2019-67035.

148 I september 2017 ble det nedsatt et lovutvalg som skal foreslå ny opplæringslov, se KD (2017a). Det står i deres mandat at loven skal «utformes i et klart og godt språk», se KD (2017b) s. 2. 
Det er altså språklig variasjon, både mellom barnelovene og artikkel 12, og mellom bestemmelsene i barnelovene. Men det er også likheter.

Rettighetssubjektet er formulert på samme måte i barnelovene som i konvensjonsbestemmelsen, og omfatter også samme gruppe personer, bortsett fra i opplæringslova, hvor rettighetssubjektet er formulert på en annen måte, som også innebærer at bestemmelsen omfatter flere.

På vilkårsiden er en likhet mellom artikkel 12 og barnelovene at de fleste bestemmelsene har ett subjektivt og ett objektivt vilkår. En forskjell er at det objektive vilkåret i barnelovene er snevrere enn i konvensjonsbestemmelsen, men dette er naturlig, jfr. kapittel 4.2.2. En annen forskjell er at flere av barnelovene har relative aldersgrenser knyttet til vilkårene. Aldersgrenser er i utgangspunktet frarådet av barnekomiteen, jfr. kapittel 3.3.2.3. I barnekomiteens avsluttende merknader til Norges fjerde rapport om oppfølging av barnekonvensjonen var komiteen positiv til at aldersgrensen i barneloven og barnevernloven var senket fra 12 til sju år, men kritiske til 12-årsgrensen i pasient- og brukerrettighetsloven. ${ }^{149}$ Aldersgrensene er ikke nevnt i de avsluttende merknadene fra 2018, til Norges femte og sjette rapporter. ${ }^{150}$

Sjuårsgrensen kan forstås som at lovgiver mener alle barn som har fylt sju bestandig er i stand til å danne seg egne synspunkter på det de aktuelle sakene dreier seg om. Men formuleringen kan også være valgt for å gjøre bestemmelsene lettere å praktisere; dersom barnet har fylt sju er det ikke nødvendig med en subjektiv vurdering, selv om noen barn som har fylt sju ikke er modne nok. Uansett hva som er årsaken, kan man si at for barn som har fylt sju, er rettigheten styrket, uten at rettigheten for yngre barn er svekket. Da er ikke aldersgrensen i strid med konvensjonen. Dette er også lovgivers uttalte begrunnelse for aldersgrensene, jfr. kapittel 4.2.2.2.

Relative aldersgrenser, både knyttet til vilkår og virkning, blir først problematiske dersom de tolkes antitetisk, slik at man for eksempel ikke legger stor vekt på meningen til et barn som er yngre enn 12, til tross for at barnet er modent. Aldersgrensene kan også medføre at man oppfatter at det er forskjellige rettigheter som følger av henholdsvis bestemmelser med og uten aldersgrense, inkludert konvensjonsbestemmelsen.

Sjuårsgrensen diskuteres ikke i den gjennomgåtte rettspraksisen, så det er vanskelig å si om aldersgrensene styrker eller svekker rettigheten, men det ser i hvert fall ikke ut til at bestemmelsene tolkes antitetisk. Situasjonen kan være en annen i forvaltningspraksis, se mer om dette i kapittel 5.

\footnotetext{
149 Concluding observations: Norway (CRC/C/NOR/CO/4) avsn. 24.

150 Concluding observations: Norway (CRC/C/NOR/CCO/5-6).
} 
En annen forskjell er at flere av bestemmelsene sier at barnet må være i stand til å danne seg «synspunkter på saken», mens barnekonvensjonen og andre barnelover kun sier «synspunkter». Dette har nok ingen rettslig betydning, men det kan likevel skape usikkerhet.

Når det gjelder formuleringen av virkningen, sier alle bestemmelsene at barnet skal få delta, i likhet med artikkel 12. Dette er riktignok formulert på ulike måter, som «seie meininga si», «medvirke» og at foreldrene skal «høyre kva barnet har å seie». En nærmere tolkning av ordene, supplert med forarbeider og rettspraksis viser at det ikke er rettslige forskjeller. Dette er likevel ikke selvsagt for enhver leser. Formuleringen «medvirkning» finner vi for $\emptyset$ vrig i bestemmelser som står i lovenes første kapittel om formål; bvl. § 1-6, oppll. § 1-1 og bhl. § 1. Det er også disse tre bestemmelsene som uttrykkelig sier at det er en rettighet.

Flere bestemmelser fokuserer på rettighetssubjektet uten å nevne at det er en rettighet, for eksempel «høve» i bl. § 31 (2). Da er det ikke klart for en leser at det er snakk om en rettighet. Det er heller ikke åpenbart at slike ulikheter ikke har rettslig betydning. Andre bestemmelser igjen er formulert som pliktbestemmelser for pliktsubjektene, for eksempel bl. § 31 (1). Samtidig sier tittelen til flere bestemmelser, som bl. $\S 31$, at det dreier seg om en rettighet.

Rett til informasjon nevnes uttrykkelig i flere bestemmelser i barnelovene, mens for artikkel 12 fremgår det av den generelle kommentaren. Det at barnet skal få uttrykke seg «freely» benyttes kun i bvl. § 1-6, som nok er den bestemmelsen som er nærmest artikkel 12 i ordlyd.

De fleste bestemmelsene sier noe om vektingen av barnets synpunkter, og da er det stort sett inntatt en direkte oversettelse av artikkel 12. B1. § 31 (2) har i tillegg en aldersangivelse.

Selv om det er språklig variasjon, medfører variasjonen i liten grad, om noen, rettslige forskjeller mellom konvensjonsbestemmelsen og barnelovene og barnelovene imellom. Ordlyden diskuteres lite i rettspraksis, så det er vanskelig å si om språklige forskjeller gir seg utslag i praksis. Men rettsanvender legger gjennomgående til grunn at den aktuelle bestemmelsen, grunnlovsbestemmelsen og konvensjonsbestemmelsen innebærer det samme. Det virker også som lovgiver har hatt fokus på å vedta bestemmelser som er i tråd med konvensjonsbestemmelsen, og i forarbeidene vises det i stor grad til artikkel 12. Det vises også til andre norske bestemmelser, og noe til utenlandsk rett.

\subsection{Annen lovgivning}

\begin{tabular}{|l|l|l|l|l|}
\hline & Rettighetssubjekt & Pliktsubjekt & Vilkår & Virkning \\
\hline
\end{tabular}




\begin{tabular}{|c|c|c|c|c|}
\hline BK art. 12 nr. 1 & «the child» & «States Parties» & $\begin{array}{l}\text { 1) «capable of } \\
\text { forming his or her } \\
\text { own views» } \\
\text { 2) «matters } \\
\text { affecting the child» }\end{array}$ & $\begin{array}{l}\text { 1) «right to } \\
\text { express those views } \\
\text { freely» } \\
\text { 2) «the views of the } \\
\text { child being given due } \\
\text { weight in accordance } \\
\text { with the age and } \\
\text { maturity of the child» }\end{array}$ \\
\hline $\begin{array}{l}\text { Fvl. § } 17(1) \\
\text { annet og tredje } \\
\text { pkt. }\end{array}$ & $\begin{array}{l}\text { «mindreårige», } \\
\text { «de» }\end{array}$ & $\begin{array}{l}\text { «[forvaltnings- } \\
\text { organer }] »^{151}\end{array}$ & $\begin{array}{l}\text { 1) «part» } \\
\text { 2) «i stand til å } \\
\text { danne seg egne } \\
\text { synspunkter på det } \\
\text { saken gjelder» }\end{array}$ & $\begin{array}{l}\text { 1) «fått mulighet til å } \\
\text { gi uttrykk for sitt syn» } \\
\text { 2) «de mindreåriges } \\
\text { syn skal tillegges } \\
\text { vekt i samsvar med } \\
\text { deres alder og mo- } \\
\text { denhet» }\end{array}$ \\
\hline Koml. § 7-2 (5) & $\begin{array}{l}\text { «personer som ikke } \\
\text { har nådd stemmer- } \\
\text { ettsalderen» }\end{array}$ & $\begin{array}{l}\text { kommuner og } \\
\text { fylkeskommu- } \\
\text { ner }^{152}\end{array}$ & $\begin{array}{l}\text { «for } \emptyset \text { vrig fyller } \\
\text { vilkårene for valg- } \\
\text { barhet og stemmer- } \\
\text { ett» }\end{array}$ & $\begin{array}{l}\text { «er valgbare, men } \\
\text { ikke pliktige til å ta } \\
\text { imot valg» }\end{array}$ \\
\hline Lotr. § 6 (4) & «barnet» & «[foreldre]» ${ }^{153}$ & $\begin{array}{l}\text { 1) «12 år eller meir» } \\
\text { 2) «om det let seg } \\
\text { gjera» }\end{array}$ & $\begin{array}{l}\text { «få seia si meining om } \\
\text { innmelding eller ut- } \\
\text { melding» }\end{array}$ \\
\hline $\begin{array}{l}\text { Pbrl. § 3-1 (1) } \\
\text { fjerde og femte } \\
\text { pkt. }\end{array}$ & «barn», «barnet» & $\begin{array}{l}\text { «[helse- } \quad \text { og } \\
\text { omsorgs- } \\
\text { tjenesten]» }^{154}\end{array}$ & $\begin{array}{l}\text { 1) «[gjennomføring } \\
\text { av helse- og } \\
\text { omsorgs- } \\
\text { tjenester]» }{ }^{155} \\
\text { 2) «i stand til å } \\
\text { danne seg egne } \\
\text { synspunkter» }\end{array}$ & $\begin{array}{l}\text { «skal legges vekt på } \\
\text { hva barnet mener, i } \\
\text { samsvar med barnets } \\
\text { alder og modenhet» }\end{array}$ \\
\hline Pbrl. § 4-4 (5) & $\begin{array}{l}\text { «barnet», «et (..) } \\
\text { barn» }\end{array}$ & $\begin{array}{l}\text { «foreldrene, andre } \\
\text { som har foreldre- } \\
\text { ansvaret eller } \\
\text { barnevern- } \\
\text { tjenesten» }\end{array}$ & $\begin{array}{l}\text { 1) «fylt sju år»: } \\
\text { 1.1) «spørsmål om å } \\
\text { samtykke til helse- } \\
\text { hjelp» } \\
\text { 2) «yngre barn»: }\end{array}$ & $\begin{array}{l}\text { 1) «gi barnet } \\
\text { informasjon og } \\
\text { anledning til å si sin } \\
\text { mening» } \\
\text { 2) «det skal legges } \\
\text { vekt på hva barnet }\end{array}$ \\
\hline
\end{tabular}

151 Jfr. fvl. § 1.

152 Jfr. koml. § 1-2.

153 Jfr. lotr. § 6-4 (1) til (3).

154 Jfr. pbrl. § 1-1.

155 Jfr. pbrl. § 3-1 (1) første pkt. 


\begin{tabular}{|c|c|c|c|c|}
\hline & & & $\begin{array}{l}\text { 2.1) «spørsmål om å } \\
\text { samtykke til helse- } \\
\text { hjelp» } \\
2.2) \ll i \text { stand til å } \\
\text { danne seg syns- } \\
\text { punkter på det } \\
\text { samtykket dreier } \\
\text { seg om» }\end{array}$ & $\begin{array}{l}\text { mener, i samsvar med } \\
\text { barnets alder og } \\
\text { modenhet» } \\
\text { 3) «er barnet fylt } 12 \\
\text { år, skal det legges stor } \\
\text { vekt på hva barnet } \\
\text { mener» }\end{array}$ \\
\hline Pbl. § 3-3 (3) & «barn og unge» & «kommunestyret» & & $\begin{array}{l}\text { «ivareta barn og } \\
\text { unges interesser i } \\
\text { planleggingen» }\end{array}$ \\
\hline $\begin{array}{l}\text { Pbl. § 5-1 (2) } \\
\text { første pkt. }\end{array}$ & «barn og unge» & «kommunen» & & $\begin{array}{l}\text { «sikre aktiv } \\
\text { medvirkning» }\end{array}$ \\
\hline $\begin{array}{l}\text { Vgml. § } 17 \text { (4) } \\
\text { første pkt. }\end{array}$ & «den mindreårige» & «vergen» & $\begin{array}{l}\text { 1) «over } 12 \text { år» } \\
\text { 2) «treffes } \\
\text { avgjørelser» }\end{array}$ & $\begin{array}{l}\text { «skal (..,) høre hva } \\
\text { den mindreårige } \\
\text { mener» }\end{array}$ \\
\hline $\begin{array}{l}\text { Vgml. § } 19(1) \\
\text { tredje pkt. }\end{array}$ & «den mindreårige» & $\ll[$ retten $]{ }^{156}$ & $\begin{array}{l}\text { 1) «over } 12 \text { år» } \\
\text { 1.1) «avgjørelse» } \\
\text { om opphør av } \\
\text { oppgaven som } \\
\text { verge } \\
\text { 2) «ellers» } \\
\text { 2.1) «avgjørelse» } \\
\text { om opphør av } \\
\text { oppgaven som } \\
\text { verge } \\
\text { 2.2) «modenhet og } \\
\text { alder tilsier at han } \\
\text { eller hun er i stand } \\
\text { til å danne seg en } \\
\text { mening om } \\
\text { saksforholdet» }\end{array}$ & $\begin{array}{l}\text { «skal }(\ldots) \text { høres før } \\
\text { avgjørelsen tas» }\end{array}$ \\
\hline $\begin{array}{l}\text { Utf. § 17-3 (1) og } \\
\text { (3) }\end{array}$ & $\begin{array}{l}\text { «barn», «dem», } \\
\text { «barnet» }\end{array}$ & & $\begin{array}{l}\text { 1) «fylt } 7 \text { år»: } \\
\text { 1.1) «vedrører dem } \\
\text { etter } \\
\text { utlendingsloven» } \\
\text { 2) «yngre barn»: } \\
\text { 2.1) «vedrører dem } \\
\text { etter } \\
\text { utlendingsloven» }\end{array}$ & $\begin{array}{l}\text { 1) «skal informeres } \\
\text { og gis anledning til å } \\
\text { bli hørt» } \\
\text { 2) «barnets syn skal } \\
\text { tillegges vekt i } \\
\text { samsvar med barnets } \\
\text { alder og modenhet» }\end{array}$ \\
\hline
\end{tabular}

156 Jfr. vgml. § 19 (1) første pkt. 


\begin{tabular}{|l|l|l|l|l|}
\hline & & $\begin{array}{l}\text { 2.2) «i stand til å } \\
\text { danne seg egne } \\
\text { synspunkter» }\end{array}$ & \\
\hline & & & & \\
\hline
\end{tabular}

\subsubsection{Rettighetssubjekt}

I pbrl. § 4-4 (5) er rettighetssubjektet «barnet», en direkte oversettelse av «the child» i artikkel 12. «Barn» er ikke definert i pasient- og brukerrettighetsloven, men en naturlig forståelse tilsier at det er personer som ikke har fylt 18 år. Loven har også et skille ved 18 år, jfr. for eksempel § 2-1 d (1), men også andre aldersgrenser, jfr. § 2-1 b (7) og § 4-4 (1). «Barn» er heller ikke definert i forarbeidene, ${ }^{157}$ men også der ser det ut til at det legges til grunn at det er personer som ikke har fylt 18 år. ${ }^{158}$ Det er ingen Høyesterettsavgjørelser om § 4-4, og ingen av lagmannsrett- og tingsrettsavgjørelsene handler om barns rett til å bli hørt. Ettersom «barn» brukes i pbrl. § 4-4 (5) uten noen nærmere aldersspesifisering, er det naturlig å legge til grunn at «barn» er personer som ikke har fylt 18 år.

Også pbrl. § 3-1, lotr. § 6 (4) og utf. § 17-3 bruker varianter av «barn». Utlendingsforskriften har også et skille ved 18 år, se for eksempel § 8-6 (1). I lotr. § 6 (4) gjelder retten barn som er «12 år eller meir», så definisjonen av «barn» er ikke avgjørende.

I fvl. § 17 (1) er rettighetssubjektet «mindreårige», og i vgml. § 17 (4) er det «den mindreårige». I vgml. $\S 8$ er «mindreårig» definert som «personer som ikke har fylt 18 år», som tilsvarer barnekonvensjonens definisjon. «Mindreårig» er ikke definert i forvaltningsloven. I Ot.prp. nr. 45 (2002-2003) side 61 uttales det for øvrig at rettighetssubjektet i fvl. § 17 (1) er «barn», og i Rt. 2015 s. 1388 avsnitt 157 vises det til denne uttalelsen.

I vgml. § 19 (1) er «den mindreårige» rettighetssubjekt. I koml. § 7-2 er rettighetssubjektet «personer som ikke har nådd stemmerettsalderen». Stemmerettsalderen er 18 år, jfr. lov 28. juni 2002 om valg til Stortinget, fylkesting og kommunestyrer (valgloven) § 2-1 (1) bokstav a.

Her er det også interessant å se på rettighetssubjektet i pbl. §§ 3-3 (3) og 5-1 (2) første punktum, selv om bestemmelsene ikke er hovedfokus for oppgaven. Årsaken er at rettighetssubjektet her er «barn og unge», et uttrykk som er uklart, og verken er definert i loven eller forarbeidene. ${ }^{159}$ Det er heller ingen aldersgrenser i loven som gir noen indikasjon. Denne formuleringen finner vi kun i plan- og bygningsloven.

157 Ot.prp. nr. 12 (1998-1999), Innst.O. nr. 91 (1998-1999), Ot.prp. nr. 65 (2005-2006), Ot.prp. nr. 104 (20082009), Prop. 75 L (2016-2017), Innst. 361 L (2016-2017).

158 Se f.eks. Ot.prp. nr. 12 (1998-1999) s. 97.

159 NOU 2001: 7, NOU 2003: 14, Ot.prp. nr. 32 (2007-2008), Innst.O. nr. 57 (2007-2008). 
Rettighetssubjektet i annen lovgivning ser altså i utgangspunktet ut til å være det samme som i konvensjonen. Samtidig har noen bestemmelser formuleringer med uklart innhold. Videre knyttes det roller til rettighetssubjektene i større grad enn det gjør i barnelovene. I fvl. § 17 (1) er det for eksempel en mindreårig «part» som er rettighetssubjekt. Dette henger samen med vilkårssiden. En annen forskjell fra barnelovene, som også har sammenheng med vilkårssiden, er at det benyttes aldersgrenser som sier at barn over en viss alder har rettigheten, uten å nevne yngre barn, som vgml. § 17 (4). Slike aldersgrenser omtales heretter som faktiske aldersgrenser. Dette henger blir behandlet nærmere i kapittel 4.3.2.

Det er i likhet med barnelovene ikke så aktuelt å se på om rettigheten er individuell eller kollektiv.

\subsubsection{Vilkår}

Det vises til det som er sagt generelt om vilkår i kapittel 4.2.2.

Det er stor variasjon i formulering av vilkårene. Det er likevel noen fellestrekk, som gjør at bestemmelsene kan kategoriseres slik: 1) bestemmelser som har to vilkår tilsvarende vilkårene i artikkel 12 nr. 1; 2) bestemmelser som har to vilkår tilsvarende vilkårene i artikkel 12 nr. 1, men disse varierer med alder; 3) andre vilkår.

\subsubsection{To vilkår som tilsvarer vilkårene i artikkel 12 nr. 1: fvl. $\S 17$ (1) annet og tredje punktum}

I fvl. § 17 (1) annet punktum er det et objektivt og et subjektivt vilkår som tilsvarer vilkårene i konvensjonsbestemmelsen, henholdsvis at den mindreårige er «part» og er «i stand til å danne seg egne synspunkter på det saken gjelder».

Første del av det subjektive vilkåret er en direkte oversettelse av konvensjonsvilkåret, og det vises til konvensjonsbestemmelsen i forarbeidene. ${ }^{160}$ Formuleringen «på det saken gjelder» finner vi ikke i konvensjonen, men det er naturlig å forstå bestemmelsen slik, jfr. kapittel 3.3.2.3. Dette kommenteres verken i forarbeidene ${ }^{161}$ eller i høyesterettspraksis.

\footnotetext{
160 Se f.eks. Ot.prp. nr. 45 (2002-2003) s. 27. Forarbeidet dreier seg om innarbeidelse av barnekonvensjonen i norsk lov, og her nevnes også andre lands gjennomføring av barnekonvensjonen, se s. 17-20.

161 Ot.prp. nr. 45 (2002-2003), Innst.O nr. 92 (2002-2003).
} 


\subsubsection{To vilkår som tilsvarer vilkårene i artikkel $12 \mathrm{nr}$. 1, men de varierer med alder: pbrl. § 4-4 (5)}

Pbrl. § 4-4 (5) har to vilkår som tilsvarer vilkårene i artikkel 12 nr. 1, men har i tillegg en relativ aldersgrense, slik at det kun er ett vilkår for barn over en viss alder.

For «yngre barn» enn sju, er det for det første et vilkår at spørsmålet dreier seg om «samtykke til helsehjelp», som tilsvarer konvensjonens objektive vilkår. Videre må barnet være «i stand til å danne seg synspunkter på det samtykket dreier seg om». Igjen er første del en direkte oversettelse av det subjektive vilkåret i artikkel 12 nr. 1, samtidig som det er naturlig å forstå konvensjonsbestemmelsen som at det er synspunkter på saken, jfr. kapittel 3.3.2.3.

For barn som har «fylt 7 år» gjelder kun det objektive vilkåret.

I forarbeidene vises det til barnekonvensjonen artikkel 12, Grl. § 104 og bl. § 31. ${ }^{162}$ Sistnevnte har også en relativ aldersgrense på sju år i annet ledd. Det fremgår av Prop. 75 L (2016-2017) side 37 at departementet foretok en grundig vurdering av aldersgrensen. Det uttales samme sted at en aldersgrense kan være et hinder for yngre barn, samtidig som det påpekes at aldersgrensen sikrer at barn som har fylt sju blir hørt. Det vises til formuleringen i bl. § 31, og uttales at hindringen for barn som ikke har fylt sju motvirkes ved at det er presisert at yngre barn har rett til å bli hørt når de er i stand til å danne seg egne synspunkter. ${ }^{163}$ Videre uttaler departementet at det ønsker å knytte ordlyden i § 4-4 til bl. § 31, og foreslår derfor å innta en sjuårsgrense, og en 12-årsgrense knyttet til vektingen av barnets synspunkter. ${ }^{164}$ Det uttales at dette innebærer «ei god tilpassing til barnekonvensjonen artikkel 12, samtidig som det er knytt opp mot Grunnlova $§ 104$ og stemmer godt overeins med barnelova $\S 31 » .{ }^{165}$ Det er som nevnt ingen relevant rettspraksis.

\footnotetext{
Vilkårene i vgml. § 19 (1) tredje punktum er bygget opp på samme måte som pbrl. § 4-4 (5). Forskjellen er at aldersgrensen er 12 år, og at den er formulert som «over» 12 år, og ikke «fylt». Det subjektive vilkåret er at den mindreåriges «modenhet og alder tilsier at han eller hun er i stand til å danne seg en mening om saksforholdet». «Modenhet og alder» finner vi igjen i vektingen i både konvensjonsbestemmelsen og mange av de norske bestemmelsene. I vgml. § 19 (1) er det altså inntatt på vilkårssiden. Det står ingenting om vekting. Utlendingsforskriften har også ett vilkår for barn som har fylt sju, og to vilkår for yngre barn.
}

\footnotetext{
162 Prop. 75 L (2016-2017) s. 87.

163 Ibid. s. 37.

164 Ibid. s. 37.

165 Ibid. s. 38.
} 


\subsubsection{Andre vilkår: vgml. § 17 (4) første punktum}

Vgml. § 17 (4) første punktum har to objektive vilkår. Det første vilkåret er at det skal «treffes avgjørelser», som tilsvarer konvensjonsbestemmelsens «matters affecting the child». «Avgjørelse» finner vi også blant annet i bl. § 31. Det andre vilkåret at den mindreårige er «over 12 år». Dette er en faktisk aldersgrense, fordi barn under 12 år etter ordlyden ikke har noen rettighet. Men i Ot.prp. nr. 110 (2008-2009) side 35 uttales det at «også barn under tolv år bør høres når sakens natur og barnets modenhet tillater det». Det er ingen rettspraksis om vgml. § 17 som omhandler retten til å bli hørt.

I NOU 2004: 16 side 104 begrunnes 12-årsgrensen med at det i bl. § 31 tidligere var en 12årsgrense, som så ble senket til sju, og at grensen i vergemålsloven $\mathrm{i}$ tråd med dette burde senkes fra 14 år til $12 .{ }^{166}$ Bruken av «over» kan være forvirrende, særlig fordi «fylt» er brukt i barnelovene. Holder det at man har fylt 12 år, eller må man ha fylt 13 for å være «over»12? I forarbeidene står det ikke noen begrunnelse eller forklaring på hva «over» innebærer. ${ }^{167}$ Det står heller ikke hvorfor vekting av synspunktene ikke nevnes, ${ }^{168}$ men vekting nevnes i forarbeidene. ${ }^{169}$

Det vises for $\emptyset$ vrig til barnekonvensjonen artikkel 12 både i NOU 2004: 16, for eksempel på side 324, og i Ot.prp. nr. 110 (2008-2009), for eksempel på side 18, men riktignok ikke i tilknytning til denne bestemmelsen spesielt. I NOUen vises det også til utenlandsk rett, men ikke direkte knyttet til § 17 (4), se for eksempel side 31.

Det er altså ikke noe subjektivt vilkår etter bestemmelsen, som gjør at den er videre enn konvensjonsbestemmelsen. Men i likhet med Grl. § 104 er det naturlig å forstå det slik at barnet må være i stand til å gjøre seg opp en mening om saken.

«Over 12 år» finner vi også i § vgml. 19 (1) tredje punktum, men der som en relativ aldersgrense. Lotr. $\S 6$ (4) har en faktisk aldersgrense, i likhet med vgml. § 17 (4) første punktum, nemlig «12 år eller meir». Dette er en tredje måte å uttrykke aldersgrenser på. Det andre vilkåret er at det må «let seg gjera» at barnet får si sin mening. Pbrl. § 3-1 har et objektivt og et subjektivt vilkår. Sistnevnte er en direkte oversettelse av det subjektive vilkåret i konvensjonsbestemmelsen. Koml. § 7-2 har ett, objektivt vilkår, «for øvrig fyller vilkårene for valgbarhet og stemmerett». Pbl. §§ 3-3 og 5-1 har ingen vilkår.

166 Se også Ot.prp. nr. 110 (2008-2009) s. 35 og Innst. 154 L (2009-2010) s. 5.

167 NOU 2004: 16, Ot.prp. nr. 110 (2008-2009), Innst. 154 L (2009-2010).

168 NOU 2004: 16, Ot.prp. nr. 110 (2008-2009), Innst. 154 L (2009-2010).

169 Ot.prp. nr. 110 (2008-2009) s. 175. Vekting nevnes også i vgml. § 33 (3) om vergens plikt til å høre den som er satt under vergemål, mv. 


\subsubsection{Virkning}

Også her er det svært stor variasjon i formuleringer, men virkningene kan likevel kategoriseres slik: 1) bestemmelser med todelt virkning i likhet med artikkel $12 \mathrm{nr} .1$; 2) bestemmelser med todelt virkning i likhet med artikkel 12 nr. 1, men som også nevner informasjon; 3) bestemmelser med andre virkninger.

\subsubsection{Virkning som tilsvarer artikkel 12 nr. 1: fvl. $\S 17$ (1) annet og tredje punktum}

I fvl. $§ 17$ (1) annet punktum står det at forvaltningsorganet «skal påse» at mindreårige parter har fått «mulighet til å gi uttrykk for sitt syn». Det er altså en pliktbestemmelse. ${ }^{170}$ «Gi uttrykk for sitt syn» er en direkte oversettelse av «express those views» i artikkel $12 \mathrm{nr}$. 1. «Mulighet» finner vi igjen i artikkel 12 nr. 2. Det står ikke noe som tilsvarer konvensjonsbestemmelsens «freely».

Forarbeidene sier lite om valget av ordlyd, ${ }^{171}$ men det presiseres i Ot.prp. nr. 45 (2002-2003) side 61 at det ikke gjelder noen aldersgrense for når rettigheten utløses, og at forvaltningen må vurdere konkret om barnet er i stand til å danne seg egne synspunkter. I Rt. 2015 s. 1388 avsnitt 157 vises det til denne uttalelsen.

Vektingen i tredje punktum er en direkte oversettelse av artikkel 12 nr. 1.

I mars i år leverte Forvaltningslovutvalget innstilling til ny forvaltningslov. ${ }^{172}$ Retten til å bli hørt foreslås inntatt i ny $\S 46$ (2), som språklig er ganske lik artikkel 12 nr. 1 og $2 .^{173}$

\subsubsection{Virkning som tilsvarer artikkel 12 nr. 1, men også nevner informasjon: pbrl. § 4-4 (5)}

Virkningen i pbrl. § 4-4 (5) er at foreldrene eller andre skal «gi barnet informasjon» og «anledning til å si sin mening». Det er altså en pliktbestemmelse. «Anledning» tilsvarer «opportunity» i artikkel 12 nr. 2, og «si sin mening» er en direkte oversettelse av «express those views» $\mathrm{i}$ artikkel 12 nr. 1. Som nevnt i kapittel 3.3.2.4 står det ikke noe om informasjon i artikkel 12, men i den generelle kommentaren. Andre forskjeller er at det står «anledning» og ikke «rett», og at det ikke står noe som tilsvarer «freely».

\footnotetext{
170 Se også Ot.prp. nr. 45 (2002-2003) s. 37.

171 Ot.prp. nr. 45 (2002-2003), Innst.O. nr. 92 (2002-2003).

172 NOU 2019: 5.

173 NOU 2019: 5 s. 30-31.
} 
Vektingen er en direkte oversettelse av konvensjonsbestemmelsen. Samtidig står det at det skal legges «stor vekt» på hva barn som har «fylt 12 år» mener. Bl. § 31 (2) har en tilsvarende formulering Se mer om forståelsen av formuleringen og forholdet til artikkel 12 i kapittel 4.2.3.2.

I Prop. 75 L (2016-2017) side 87 står det at ved utformingen av femte ledd var det spesielt sett hen til bl. § 31, Grl. § 104 og barnekonvensjonen artikkel 12, og på side 37-38 står det som nevnt at bestemmelsen ble endret for å samsvare med disse bestemmelsene. Det står ingen begrunnelse for 12-årsgrensen. Rettspraksis om bestemmelsen dreier seg ikke om retten til å bli hørt.

Både pbrl. § 3-1 (1) og utf. § 17-3 (1) og (3) har todelt virkning, og nevner i tillegg informasjon. I begge bestemmelsene er vektingen en direkte oversettelse av konvensjonsbestemmelsen. Pbrl. § 3-1 (1) er til forskjell fra § 4-4 (5) formulert som en rettighetsbestemmelse. Også utf. § 17-3 har rettighetssubjektet i fokus. Ingen av dem knytter alder til virkningen.

\subsubsection{Andre virkninger: vgml. $§ 17$ (4) første punktum}

Virkningen etter vgml. § 17 (4) første punktum er at vergen «skal (...) høre hva den mindreårige mener». Det er altså en pliktbestemmelse. «Skal (...) høre» tilsvarer «be heard» i artikkel 12 nr. 2. Det er ingenting som tilsvarer «freely» i bestemmelsen.

Det står heller ingenting om vekting, til forskjell fra konvensjonsbestemmelsen. Det står altså at den mindreårige skal høres, men ikke at retten har noen plikt til å vektlegge den mindreåriges syn. Samtidig står det i Ot.prp. nr. 110 (2008-2009) side 175: «Den mindreåriges mening skal normalt tillegges $\varnothing \mathrm{kt}$ vekt etter hvert som han eller hun blir eldre og mer moden.»

Det er ellers lite å finne i forarbeidene om språklige valg på virkningssiden, ${ }^{174}$ og det er ingen relevant rettspraksis.

Vgml. $§ 19$ (1) er til forskjell fra $\S 17$ (4) formulert med fokus på rettighetssubjektet. I likhet med $\S 17$ (4) brukes «høre» om virkningen, og det står ingenting om vekting. Samtidig står det i Ot.prp. nr. 110 (2008-2009) side 37 at «Barnets mening må tillegges vekt ut fra hvor gammelt og modent det er», og at bestemmelsen har likhetstrekk med bl. $\S 31$. Også lotr. $§ 6$ (4) er formulert med fokus på rettighetssubjektet; barnet «skal få seia si meining».

I pbl. § 3-3 (3) står det at kommunestyret skal «ivareta barn og unges interesser i planleggingen», og i $\S$ 5-1 (2) står det at kommunen skal «sikre aktiv medvirkning». Det står ingenting om vekting i de to bestemmelsene, men det henger nok sammen med bestemmelsenes formulering. Koml. § 7-2 sier ikke direkte at det er en rett til å bli hørt eller liknende, og skiller seg veldig fra artikkel 12.

174 NOU 2004: 16, Ot.prp. nr. 110 (2008-2009), Innst. 154 L (2009-2010). 


\subsubsection{Oppsummering og vurdering}

Det er stor språklig variasjon, både mellom annen lovgivning og artikkel 12, mellom annen lovgivning og barnelovene, og mellom bestemmelsene i annen lovgivning. Men det er også likheter.

Når det gjelder formulering av rettighetssubjektet, er det en overvekt av «barn» og «mindreårige». Førstnevnte er en direkte oversettelse av «child». Begge omfatter samme personer som både «child» i artikkel 12 og rettighetssubjektet i de fleste barnelovene. Men det er også andre, mindre klare formuleringer, som «barn og unge».

Det er større variasjon i antall vilkår og formulering av vilkårene i annen lovgivning enn i konvensjonsbestemmelsen og barnelovene, jfr. kapittel 4.3.2, som kan være kompliserende for en leser. Det er både bestemmelser med vilkår som tilsvarer artikkel 12 og bestemmelser med andre vilkår. Det er også bestemmelser med relative aldersgrenser knyttet til vilkårene. Det vises til det som er skrevet om dette i kapitlene 4.2.2.2 og 4.2.4. På samme måte som for barnelovene er de objektive vilkårene smalere enn i konvensjonsbestemmelsen, uten å være i strid med konvensjonen, jfr. kapittel 4.2.2.

Faktiske aldersgrenser er i strid med konvensjonen, ettersom barn under aldersgrensen ikke har rettigheter etter ordlyden. Faktiske aldersgrenser har altså rettslig betydning. Barn over aldersgrensen får derimot styrket rettigheten, fordi det i likhet med de relative aldersgrensene ikke stilles subjektive vilkår til dem. Samtidig er ikke nødvendigvis meningen at barn under aldersgrensen ikke har en rett til å bli hørt, jfr. om vgml. § 17 (4) i kapittel 4.3.2.3. Barnet vil også uansett ha en rett etter mrl. $\S \S 2$ og 3 . Faktiske aldersgrenser kan nok også medføre ulikheter i praksis, men det er vanskelig å si sikkert, ettersom rettspraksis om retten til å bli hørt i annen lovgivning er begrenset, og det på grunn av oppgavens omfang ikke har vært mulig å gjennomgå forvaltningspraksis. Faktiske aldersgrenser kan $i$ hvert fall skape forvirring for lesere som ser på både konvensjonsbestemmelsen og bestemmelser med slike aldersgrenser.

I likhet med barnelovene varierer det om det står «synspunkter»og «synspunkter på saken». Jeg viser til det som er skrevet om dette i kapittel 4.2.4.

Når det gjelder formuleringen av virkningen, gir alle bestemmelsene uttrykk for at barnet skal få delta, i likhet med artikkel 12 og barnelovene. Men formuleringene varierer nok i enda større grad enn i barnelovene; for eksempel «fått mulighet til å gi uttrykk for sitt syn» i fvl. § 17 (1), «skal (..,) høre hva den mindreårige mener» i vgml. § 17 (4), «ivareta barn og unges interesser i planleggingen» i pbl. § 3-3 (3) og «er valgbare, men ikke pliktige til å ta imot valg» i koml. § 
7-2 (5). I flere av bestemmelsene som ikke er hovedfokus, som de to sistnevnte, finner vi formuleringer som skiller seg veldig fra både artikkel 12, barnelovene og andre bestemmelser i annen lovgivning.

Det at barnet skal få uttrykke seg «freely» finner vi ikke i annen lovgivning. Flere bestemmelser sier heller ingenting om vekten av barnets synspunkter. Dette kan forstås som at den mindreåriges mening er mindre viktig i saker som disse bestemmelsene regulerer, enn bestemmelser som sier noe om vekten. Samtidig fremgår det av forarbeidene til flere av disse bestemmelsene, som vgml. § 17 (4), at synspunktene skal vektlegges. Det følger også helt klart av konvensjonsteksten. Da skaper det unødvendig usikkerhet å ikke innta dette i lovteksten. Der vekting er inntatt i ordlyden, er det gjennomgående en direkte oversettelse av artikkel 12.

I likhet med barnelovene er noen bestemmelser formulert med fokus på rettighetssubjektet, mens andre er formulert som pliktbestemmelser for pliktsubjektene. Ingen av bestemmelsene bruker ordet rettighet, til forskjell fra både konvensjonsbestemmelsen og flere bestemmelser i barnelovene. Videre nevner noen bestemmelser uttrykkelig informasjon.

Oppsummeringsvis er rettigheten $\mathrm{i}$ annen lovgivning ofte formulert mer kortfattet enn i konvensjonen og barnelovene. Jevnt over viser lovgiver i forarbeidene til barnekonvensjonen og andre norske bestemmelser, særlig bl. § 31, og litt til lovgivning i andre land. Likevel er det større språklig variasjon her enn i barnelovene, og større grad av rettslig ulikhet. Det ser likevel ikke ut til at ulikhetene materialiserer seg i rettspraksis. Samtidig er det flere av bestemmelsene det ikke finnes relevant rettspraksis om.

\section{$5 \quad$ Avsluttende vurderinger}

Her vil jeg forsøke å besvare spørsmålene oppstilt i kapittel 1.2.

Analysen og sammenlikningen i kapittel 4 viser at det er språklig variasjon mellom barnekonvensjonen artikkel 12 og de norske bestemmelsene. Det neste spørsmålet er om språket i de norske bestemmelsene er dekkende. En utfordring med å svare på dette er at konvensjonsbestemmelsen er generell, mens de norske særlovene gjelder på avgrensede rettsområder og i konkrete situasjoner. For flere av bestemmelsene ville det derfor ikke vært hensiktsmessig med en direkte oversettelse av artikkel 12, slik at noe språklig variasjon er naturlig. Det er likevel flere eksempler på formuleringer som ikke er dekkende. Et tydelig eksempel er faktiske aldersgrenser, for eksempel i vgml. § 17 (4). Et annet eksempel er «gjelder»i Grl. § 104. Formuleringene medfører at rettigheten etter disse bestemmelsene er snevrere enn etter konven- 
sjonsbestemmelsen. Bestemmelsene i annen lovgivning er nok i mindre grad dekkende enn bestemmelsene i barnelovene, jfr. kapittel 4.3. Formuleringene av rettighetssubjektet ser ut til å være dekkende, selv om det også er formuleringer som er uklare, og hvor man har få indikasjoner på hva lovgiver har ment.

Språket i de norske bestemmelsene er ikke enhetlig. Det er størst språklig variasjon i annen lovgivning, både blant disse bestemmelsene, mellom annen lovgivning og barnelovene, og mellom annen lovgivning og barnekonvensjonen, jfr. kapittel 4.3. For eksempel er det kun i annen lovgivning vi finner faktiske aldersgrenser. Her er det også størst variasjon i formulering av rettighetssubjektet. Videre er det en rekke ulike formuleringer av vilkår og virkning, som både skiller seg fra andre bestemmelser i annen lovgivning, og fra konvensjonsbestemmelsen, grunnlovsbestemmelsen og barnelovene.

Når bestemmelsene ikke er dekkende, eller det er annen variasjon mellom konvensjonsbestemmelsen og norske bestemmelser eller blant de norske bestemmelsene, kan det ha rettslig betydning. Rettslige ulikheter finner vi både i annen lovgivning og i Grunnloven. Men de rettslige forskjellene materialiserer seg i liten grad i rettspraksis. Samtidig er det flere av bestemmelsene som det er lite relevant rettspraksis om.

Bestemmelsene tolkes altså i samsvar med konvensjonen, se for eksempel kapitlene 4.1.3 og 4.2.3.2. Dette er i tråd med presumsjonsprinsippet. Samtidig har ikke språklige spørsmål kommet på spissen i de gjennomgåtte sakene. Vi ser også at lovgiver ikke nødvendigvis har ment at bestemmelsene i særlovene skal være snevrere enn konvensjonsbestemmelsen, til tross for ordlyden. Et eksempel på dette er forarbeidsuttalelsene om at også barn under 12 kan høres etter vgml. § 17 (4) første punktum, jfr. kapittel 4.3.2.3.

Selv om språklige forskjeller har liten betydning i rettspraksis, kan det ha betydning i forvaltningspraksis. Forvaltningens rettskildebruk er noe forskjellig fra domstolenes; forvaltningen anvender ofte færre rettskilder enn domstolene, som kan ha sammenheng med at mange i forvaltningen ikke er jurister, og det legges stor vekt på rundskriv og forvaltningspraksis. ${ }^{175} \mathrm{I}$ tillegg holder forvaltningsorganene seg gjerne tettere til særlovens lovtekst, og da kan det være lettere å overse rettigheter som ikke fremgår eksplisitt i særlovgivningen. ${ }^{176}$

175 Eriksen (2019) s. 306, Helset (1986) s. 263-264.

176 Personlig kommunikasjon i samtale med Jon Christian Nordrum, førsteamanuensis ved UiO, 21. oktober 2019. Se også Høgberg (2019), Tønder (2019) og Eriksens uttalelser i Gilbrant (2019), alle om NAV-avsløringen fra oktober. NAV-saken handler riktignok om mer enn bare forvaltningens rettsanvendelse, jfr. disse kildene. Men flere har påpekt at feilen henger sammen med at EØS-rettigheten ikke fremgår klart av den aktuelle bestemmelsen, se nevnte kilder. 
Språklige forskjeller kan også skape språklig uklarhet, som igjen kan skape rettsusikkerhet. Både konvensjonsbestemmelsen og grunnlovsbestemmelsen kommer til anvendelse i situasjoner hvor også særlovene anvendes. For en leser som slår opp i flere bestemmelser om retten til å bli hørt, kan mangfoldet i formuleringer føre til forvirring og usikkerhet. Dette gjelder selv om forskjellene ikke nødvendigvis innebærer innholdsmessige variasjoner.

Noen eksempler på spørsmål en leser kan sitte igjen med som følge av språklig uklarhet er: Har lovgiver ment at rettighetssubjektet i fvl. § 17 (1) er noen andre enn i konvensjonsbestemmelsen, ettersom det står «mindreårig» og ikke «barn»? Hva er forskjellen på konvensjonens «child» og plan- og bygningslovens «barn og unge»? Dersom Grunnloven og barnekonvensjonen gir samme rettighet, hvorfor står det «gjelder» i grunnlovsbestemmelsen, og ikke «påvirker»? Er «skal foreldra høyre kva barnet har å seie» i bl. § 31 (1) og «rett til medverknad» i oppll. § 1-1 det samme? Betyr formuleringene «fylt», «over» og «mer enn» i forbindelse med aldersgrenser det samme?

Også relative aldersgrenser kan føre til rettsusikkerhet. Ordlyden er ikke i strid med artikkel 12, men aldersgrensene kan medføre at rettigheten i slike bestemmelser forstås annerledes enn $\mathrm{i}$ bestemmelsene uten relative aldersgrenser. De kan også gjøre det lettere å overse yngre barn.

Videre er det en del bestemmelser som ikke nevner vekting av synspunktene, særlig i annen lovgivning. Det er likevel naturlig å forstå bestemmelsene som at synspunktene skal vektlegges, ellers ville rettigheten hatt begrenset betydning. En naturlig forståelse av retten til å bli hørt tilsier at man har en rett til å uttale seg, kombinert med at noen har en plikt til å lytte $o g$ å ta synspunktene alvorlig, altså å vektlegge synspunktene. ${ }^{177}$ Det har liten verdi å få uttrykke meningen sin dersom ingen behøver å ta den alvorlig. Først da får barn mulighet til å påvirke situasjoner de berøres av, og artikkel 12 må forstås som at det er dette som er hensikten med rettigheten. Men en leser kan likevel tenke at bestemmelsene er formulert forskjellig fordi lovgiver har ment at de er forskjellige - ellers kunne jo lovgiver formulert bestemmelsene mer i tråd med hverandre.

Enda et eksempel er at noen bestemmelser er formulert som pliktbestemmelser, mens andre er rettighetsbestemmelser. Det er også en rekke bestemmelser som er formulert med fokus på hva rettighetssubjektet skal få, uten å bruke ordet «rettighet». For eksempel er virkningen i svært mange bestemmelser formulert som «høve», «mulighet» eller «anledning» til å bli hørt. Dette er svakere formuleringer enn de rene rettighetsbestemmelsene, og det er ikke åpenbart at disse bestemmelsene gjennomfører en rett til å bli hørt. I Ot.prp. nr. 46 (2007-2008) s. 24 fremgår det også at høringsinstanser mente forslaget om at elever skulle ha «høve» til medvirkning ikke

177 Sandberg (2016) s. 93. 
var tilstrekkelig. Når man ser på alle bestemmelsene inntatt i skjemaene ser det ut til å være omtrent likt fordelt mellom barnelovene og annen lovgivning hvor mange bestemmelser som er formulert med fokus på henholdsvis rettighetssubjektet og pliktsubjektet.

Det er ikke noe enkelt eller klart svar på hva som er årsaken til språklige variasjoner, fordi forarbeidene ofte sier lite om bakgrunnen for lovgivers språklige valg. En mulig forklaring er at særlovene er spesielle, mens konvensjonsbestemmelsen og grunnlovsbestemmelsen er generelle. Formuleringene er derfor tilpasset de aktuelle lovene og rettsområdene, som har forskjellige perspektiver og språklig stil. Variasjonen i formulering av vilkåret som tilsvarer barnekonvensjonens «matters affecting the child», jfr. kapittel 4.2.2, er et tydelig eksempel på dette.

Det kan også ha betydning om det er en formålsbestemmelse, som bvl. § 1-6, eller om bestemmelsen gjelder i konkrete situasjoner, som pbrl. § 4-4 (5). En årsak til at vi finner størst variasjon blant annen lovgivning kan være at det er enklere å formulere rettigheten i tråd med konvensjonen her enn i annen lovgivning, fordi barnelovene nettopp dreier seg om barn.

Samtidig ser det ut til at lovgiver ofte ikke har et veldig bevisst forhold til språklige valg. Selv om det i forarbeidene vises både til konvensjonen og norsk og utenlandsk rett, diskuteres betydningen av termene, hva som skiller dem og hvorfor bestemte termer er brukt svært lite. Grl. $\S 104$ og flere av bestemmelsene med relative aldersgrenser, som bl. § 31 (2), skiller seg ut. Her er det tydelig at språket er gjennomtenkt.

De to neste spørsmålene, hvilke vurderinger som er gjort ved gjennomføringen av rettigheten og om språkarbeidet er systematisk, henger både sammen med hverandre og med det som ble sagt i avsnittet over. Det er ikke helt lett å svare på disse spørsmålene fordi språklige valg ofte ikke diskuteres inngående i forarbeidene. Men der de språklige valgene diskuteres henvises det til både barnekonvensjonen, Grunnloven og annen norsk lovgivning, og også noe til utenlandsk rett. Det tyder på at lovgiver har vært opptatt av konsistens, både mellom lover og mellom lov og Grunnlov. Når det gjelder Grl. § 104, ser det derimot ut til at lovgiver har ønsket en snevrere rettighet enn i konvensjonsbestemmelsen.

Oppsummeringsvis er det altså stor språklig variasjon, spesielt i annen lovgivning, som helt klart kan medføre språklig uklarhet, og som noen ganger innebærer rettslige ulikheter. Samtidig ser det i forarbeidene ut til at lovgiver har vært opptatt av konsistens, og der det finnes relevant rettspraksis, legger rettsanvender også til grunn at bestemmelsene gir samme rettighet som hverandre og artikkel 12. 
Det er samtidig viktig å være oppmerksom på at mange av dem som forholder seg til bestemmelsene om barns rett til å bli hørt ikke har juridisk bakgrunn, og derfor ikke har samme mulighet eller insentiv til å opps $\varnothing$ ke andre rettskilder. I mange av bestemmelsene kunne lovgiver med fordel valgt formuleringer som er nærmere både konvensjonsbestemmelsen og andre norske bestemmelser. På denne måten kunne man redusert språklig uklarhet og rettsusikkerhet, og styrket barns rettssikkerhet. For eksempel burde det stå uttrykkelig i alle bestemmelsene at det er en rettighet. Dette bør være mulig uten store problemer, også i pliktbestemmelsene. Faktiske aldersgrenser bør også fjernes, slik at formuleringene av barns rett til å bli hørt samsvarer med formuleringen i barnekonvensjonen, som også er norsk rett, og går foran bestemmelsene med faktiske aldersgrenser, jfr. mrl. $\S 2$ og 3. Ved å gjøre det tydeligere i særlovgivningen at alle barn har rett til å bli hørt blir rettigheten mer tilgjengelig. Når man ser på den relativt nye bvl. § 1-6, den foreslåtte bvl. § 1-5, den foreslåtte fvl. § 46 (2) og mandatet til barnelovutvalget, ser det ut til å være en positiv utvikling hvor språket i nyere bestemmelser blir enda likere formuleringene i konvensjonsbestemmelsen.

Denne oppgaven har bare tatt for seg én rettighet av mange som følger av Norges folkerettslige forpliktelser. Når det er så stor språklig variasjon her, er det grunn til å tro at dette også gjelder andre rettigheter som følger av folkeretten. Det hadde derfor vært både interessant og viktig med en bredere kartlegging av språket i bestemmelser som gjennomfører slike rettigheter. 


\section{Kildeliste}

\section{Litteratur}

Bøker, artikler og liknende

Aarli, Ragna og Synne S. Mæhle. Juridisk metode i et nфtteskall. 1. utg., Oslo: Gyldendal, 2018.

Backer, Inge L.

«Om gjennomføring av barnekonvensjonen i norsk rett.» i Bonus pater familias - Festskrift til Peter Lфdrup. Kirsti Strøm Bull, Viggo Hagstrøm og Steinar Tjomsland red., Oslo: Gyldendal akademisk, 2002, s. 69-88 (sitert fra Lovdata.no).

Blandhol, Sverre.

«Er rettsanvendelsen i EU-domstolen og Menneskerettsdomstolen vesensforskjellig fra norsk rettskildelære?», Lov og Rett nr. 5-6 (2005), s. 316-327 (Sitert fra Lovdata.no).

Eriksen, Christoffer C. «Forvaltningspraksis som rettskildefaktor.» i Juridisk metode og tenkemåte. Alf Petter Høgberg og Jørn Øyrehagen Sunde red., 1. utg., Oslo: Universitetsforlaget, 2019, s. 293-333.

Fosmark, Per Racin. «Merknad til barnevernloven.» i Lovdata 2019 hentet 6.11.2019.

Haugli, Trude. «Barnerett - utviklingstrekk og utfordringer.» Tidsskrift for familierett, arverett og barnevernrettslige spфrsmål nr. 1-2 (2010), s. 5-24 (Sitert fra Lovdata.no).

Helset, Per. «Innledning til rettskildelæren.» Jussens Venner nr. ikke oppgitt (1986), s. 261-296 (Sitert fra Lovdata.no).

Høstmælingen, Njål, Elin S. «Forord.» i Barnekonvensjonen. Barns rettigheter $i$ 
Kjørholt og Kirsten Sandberg.

Mestad, Ola.

Michalsen, Dag.

Ruud, Morten og Geir Ulfstein.

Sandberg, Kirsten.

Smith, Carsten.

Smith, Lucy.

Smith, Lucy.

UNICEF.

Østerud, Øyvind.
Norge. Njål Høstmælingen, Elin Saga Kjørholt og Kirsten Sandberg red., 3. utg., Oslo: Universitetsforlaget, 2016, s. 5-6.

«Rettens kilder og anvendelse.» i Juridisk metode og tenkemåte. Alf Petter Høgberg og Jørn Øyrehagen Sunde red., 1. utg., Oslo: Universitetsforlaget, 2019, s. 77-113.

«Internasjonaliseringens historie i norsk rett.» Lov og Rett nr. 8 (2001), s. 451-473.

Innføring i folkerett. 5. utg., Oslo: Universitetsforlaget, 2018.

«Barns rett til å bli hørt.» i Barnekonvensjonen. Barns rettigheter i Norge. Njål Høstmælingen, Elin Saga Kjørholt og Kirsten Sandberg red., 3. utg., Oslo: Universitetsforlaget, 2016, s. 92-122.

«Fra konvensjon til lov.» Mennesker og Rettigheter nr. ikke oppgitt (1999) s. 266-274 (sitert fra Lovdata.no).

«Nyere utvikling i barneretten.» Tidsskrift for familierett, arverett og barnevernrettslige spфrsmål nr. 2 (2008), s. 84-95 (Sitert fra Lovdata.no).

«FNs konvensjon om barnets rettigheter.» i Barnekonvensjonen. Barns rettigheter i Norge. Njål Høstmælingen, Elin Saga Kjørholt og Kirsten Sandberg red., 3. utg., Oslo: Universitetsforlaget, 2016, s. 17-30.

Implementation handbook for the convention on the rights of the child. 3. utg., UNICEF, 2007. https://www.unicef.org/publications/files/Implementation_Handbook for the Convention_on_the_Rights_of_the_Child.pdf hentet 21.11.19.

«Rettsliggjøring og demokrati.» Tidsskrift for samfunnsforskning nr. 4 (2006), s. 613-621. 
Juridiske masteroppgaver

Bangsund, Jan Erik. Juridisk oversettelse - hvorfor så vanskelig? Universitetet i Oslo, 2010.

Carlsen, Stine M. B. Klart lovspråk i helsepersonelloven? - Med vekt på en analyse av praksis fra Helsepersonellnemnda. Universitetet i Oslo, 2018.

\section{Ordbøker}

Ordnett.no(a). «Matter». I Stor engelsk-norsk ordbok. (u.å.). Kunnskapsforlaget. https://www.ordnett.no/search?language=en\&phrase=matter\&selected-

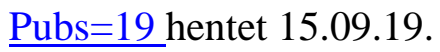

Ordnett.no(b). «Affect». I Stor engelsk-norsk ordbok. (u.å.). Kunnskapsforlaget. https://www.ordnett.no/search?language $=$ en \&phrase $=$ affect\&selected=\&selectedPubs=19 hentet 25.11.19.

Ordnett.no(c). «Gjelde». I Stor norsk ordbok. (u.å.). Kunnskapsforlaget. https://www.ordnett.no/search?language=no\&phrase=gjelde\&selectedPubs=55 hentet 17.11.19.

Ordnett.no(d). «Vedrøre». I Stor norsk ordbok. (u.å.). Kunnskapsforlaget. https://www.ordnett.no/search?language $=$ no \&phrase $=$ vedr $\% \mathrm{C} 3 \% \mathrm{~B} 8 \mathrm{re} \&$ selected Pubs=55\&showSignLanguage $=$ hentet 13.10 .19 .

Ordnett.no(e). «Betydning». I Stor norsk ordbok. (u.å.). Kunnskapsforlaget. https://www.ordnett.no/search?language=no\&phrase=betydning\&selectedPubs=55 hentet 12.10.19.

Ordnett.no(f). «Høve». I Nynorsk ordbok. (u.å.). Kunnskapsforlaget. https://www.ordnett.no/search?phrase $=\mathrm{h} \% \mathrm{C} 3 \% \mathrm{~B} 8 \mathrm{ve} \&$ publications $=20 \&$ articleRe$\underline{\text { fid }=13319107 \& \text { selectedPubs }=20}$ hentet 13.10.19. 
Ordnett.no(g). «Medvirkning». I Stor norsk ordbok. (u.å.). Kunnskapsforlaget. https://www.ordnett.no/search?language=no\&phrase=medvirk-

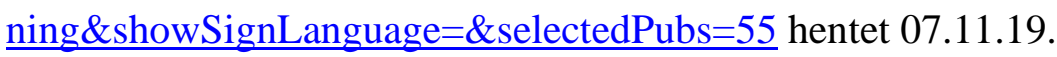

Annet

BFD (2018a).

«Nytt utvalg skal gjennomgå barneloven.» 2018.

https://www.regjeringen.no/no/aktuelt/nytt-utvalg-skal-gjennomga-barneloven/id2621496/ hentet 13.10 .19 .

BFD (2018b).

«Utvalgsmandat til arbeidet med ny barnelov.» 2018. https://www.regjeringen.no/contentassets/a02fb0c0772b4817832ce409f04eaf7c/barnelovutvalg---mandat.pdf hentet 13.10.19.

BFD. «Høring - forslag til ny barnevernslov.» 2019. https://www.regjeringen.no/no/dokumenter/horing---forslag-til-ny-barnevernslov/id2639982/ hentet 31.08.19.

Difi. «Klart lovspråk.» 2015. https://www.difi.no/fagomrader-og-tjenester/klart-sprak-og-brukerinvolvering/klart-lovsprak hentet 02.07.19.

Gilbrant, Jørgen. «Jussprofessor slår EØS-alarm: Nordmenn har skjulte rettigheter.»Dagbladet, https://www.dagbladet.no/nyheter/nordmenn-har-skjulte-rettigheter/71780409 hentet 24.11.19.

Høgberg, Benedikte M. «NAV-skandalen: Juristene i glasshuset.» Juridika Innsikt, https://juridika.no/innsikt/juristene-iglasshus-nav-saken hentet 24.11.19.

KD (2017a).

«Utval skal sjå på opplæringslova.» 2017. https://www.regjeringen.no/no/aktuelt/utval-skal- 
sja-pa-opplaringslova/id2572742/ hentet

07.11.19.

KD (2017b).

«Mandat for offentlig lovutvalg på grunnopplæ-

ringens område.» 2017. https://www.regje-

ringen.no/conten-

tassets/21eaef6110874a2a87281564b2d5614f/ma

ndat.pdf hentet 07.11.19.

KMD.

«Klart språk blir del av jusutdanningen». 2016

https://www.regjeringen.no/no/aktuelt/klart-

sprak-blir-del-av-jusutdanningen/id2509688/ hentet 14.01.19.

Kvarenes, Margrethe.

«Språkrådet + Difi = Klart språk i staten». 2009

https://www.sprakradet.no/Vi-og-vart/Publikasjoner/Spraaknytt/Arkivet/Spraknytt-2009/Sprak-

nytt-12009/Sprakradet--Difi--Klart-sprak-i-staten/ hentet 02.07.19

Språkrådet.

Klarspråk. (2013), https://www.sprakra-

det.no/globalassets/vi-og-vart/publikasjo-

ner/2013-klarsprak-bm.pdf hentet 14.01.19.

Språkrådet.

«Prosjektet 'Klart lovspråk'». u.å.

https://www.sprakradet.no/Klarsprak/om-klar-

sprak/om-oss/klart-lovsprak/ hentet 02.07.19.

Tønder, Bård.

«NAV-saken, domstolene og lovens ordlyd.»

Rett24, https://rett24.no/articles/nav-saken-dom-

stolene-og-lovens-ordlyd hentet 24.11.19.

\section{Norske rettskilder}

\section{Lover}

1814 Lov 17. mai 1814 Kongeriket Norges Grunnlov (Grunnloven) 
(bokmål og nynorsk språkversjon).

1967 Lov 10. februar 1967 om behandlingsmåten i forvaltningssaker (forvaltningsloven).

1969 Lov 13. juni 1969 om trudomssamfunn og ymist anna.

1981 Lov 8. april 1981 om barn og foreldre (barnelova).

1988 Lov 8. juli 1988 om anerkjennelse og fullbyrding av utenlandske avgjørelser om foreldreansvar $\mathrm{m} v$ og om tilbakelevering av barn (barnebortføringsloven).

1992 Lov 17. juli 1992 om barneverntjenester (barnevernloven).

1998 Lov 17. juli 1998 om grunnskolen og den vidaregåande opplæringa (opplæringslova).

1999 Lov 21. mai 1999 om styrking av menneskerettighetenes stilling i norsk rett (menneskerettsloven).

1999 Lov 2. juli 1999 om pasient- og brukerrettigheter (pasient- og brukerrettighetsloven).

2002 Lov 28. juni 2002 om valg til Stortinget, fylkesting og kommunestyrer (valgloven).

2005 Lov 17. juni 2005 om barnehager (barnehageloven).

2005 Lov 17. juni 2005 om mekling og rettergang i sivile tvister (tvisteloven).

2008 Lov 15. mai 2008 om utlendingers adgang til riket og deres opphold her (utlendingsloven).

2008 Lov 27. juni 2008 om planlegging og byggesaksbehandling (plan- og bygningsloven).

2010 Lov 26. mars 2010 om vergemål (vergemålsloven).

2017 Lov 16. juni 2017 om adopsjon (adopsjonsloven).

2018 Lov 22. juni 2018 om kommuner og fylkeskommuner (kommuneloven).

Forskrifter

2009 Forskrift 15. oktober 2009 om utlendingers adgang til riket og deres opphold her (utlendingsforskriften).

2014 Forskrift 1. juni 2014 om medvirkning og tillitsperson (medvirkningsforskriften).

\section{Forarbeider}

NOU 1977: 35

Lov om barn og foreldre (barneloven).

Ot.prp. nr. 62 (1979-1980)

Om lov om barn og foreldre (barneloven).

Innst.O. nr. 30 (1980-1981)

Innstilling fra justiskomitéen om lov om barn og foreldre (barnelova). 
Ot.prp. nr. 52 (1987-1988)

Ot.prp. nr. 44 (1991-1992)

Ot.prp. nr. 12 (1998-1999)

Innst.O. nr. 91 (1998-1999)

NOU 2001: 7

Ot.prp. nr. 29 (2002-2003)

Ot.prp. nr. 45 (2002-2003)

Innst.O nr. 92 (2002-2003)

Innst.O. nr. 96 (2002-2003)

NOU 2003: 14
Om A Lov om anerkjennelse og fullbyrding av utenlandske avgjфrelser om foreldreansvar m.v og om tilbakelevering av barn. B Lov om samtykke til ratifikasjon av Europarådkonvensjonen 20 mai 1980 om anerkjennelse og fullbyrding av avgjørelser om foreldreansvar og om gjenopprettelse av foreldreansvar og Haagkonvensjonen 25. oktober 1980 om de sivile sider ved internasjonal barnebortføring.

Om lov om barneverntjenester (barnevernloven).

Lov om pasientrettigheter (pasientrettighetsloven).

Innstilling fra sosialkomiteen om lov om pasientrettigheter (pasientrettighetsloven).

Bedre kommunal og regional planlegging etter plan- og bygningsloven. Planlovutvalgets første delutredning.

Om lov om endringer i barneloven mv. (Nye saksbehandlingsregler $i$ barnefordelingssaker for domstolene $m v)$.

Om lov om endring i menneskerettsloven mv. (innarbeiding av barnekonvensjonen i norsk lov).

Innstilling fra justiskomiteen om lov om endring $i$ menneskerettsloven $m v$. (innarbeiding av Barnekonvensjonen $i$ norsk lov).

Innstilling fra familie-, kultur- og administrasjonskomiteen om lov om endringer $i$ barneloven mv. (Nye saksbehandlingsregler $i$ barnefordelingssaker for domstolene $m v$.).

Bedre kommunal og regional planlegging etter plan- og bygningsloven II. Planlovutvalgets utredning med lovforslag.

Vergemål. 
Ot.prp. nr. 65 (2005-2006)

Ot.prp. nr. 32 (2007-2008)

Ot.prp. nr. 46 (2007-2008)

Innst.O. nr. 57 (2007-2008)

NOU 2008: 9

Innst.O. nr. 22 (2008-2009)

Ot.prp. nr. 104 (2008-2009)

Ot.prp. nr. 110 (2008-2009)

Innst. 154 L (2009-2010)

NOU 2011: 20

Prop. 43 L (2011-2012)

Dokument 16 (2011-2012)

Dokument 19 (2011-2012)
Om lov om endringer i psykisk helsevernloven og pasientrettigjetsloven m.v.

Om lov om planlegging og byggesaksbehandling (plan-og bygningsloven) (plandelen).

Om lov om endringer i opplaeringslova (Om formålet med opplacringen).

Innstilling fra energi- og miljøkomiteen om lov om planlegging og byggesaksbehandling (plan- og bygningsloven) (plandelen).

Med barnet i fokus.

Innstillingen fra kirke-, utdannings- og forskningskomiteen om lov om endringer $i$ opplaeringslova (om formålet med opplaeringen).

Om lov om endringer i barnelova mv. (flytting, delt bosted, samvar, vold $m v$.

Om lov om vergemål (vergemålsloven).

Innstilling fra justiskomiteen om lov om vergemål (vergemålsloven).

Ungdom, makt og medvirkning.

Endringer i barnevernloven.

Rapport fra Menneskerettighetsutvalget om menneskerettigheter i Grunnloven.

Rapport til Stortingets presidentskap fra Grunnlovsspråkutvalget om utarbeidelse av språklig oppdaterte tekstversjoner av Grunnloven på bokmål og nynorsk. 
Grunnlovsforslag 30 (2011-2012) Grunnlovsforslag fra Per-Kristian Foss, Martin Kolberg, Marit Nybakk, Jette F. Christensen, Anders Anundsen, Hallgeir H Langeland, Per Olaf Lundteigen, Geir Jørgen Bekkevold og Trine Skei Grande om grunnlovfesting av sivile og politiske menneskerettigheter.

NOU 2012: 2

Utenfor og innenfor. Norges avtaler med EU.

Prop. 85 L (2012-2013)

Endringer $i$ barnelova (barneperspektivet $i$ foreldretvister).

Innst. 374 L (2012-2013)

Innstilling fra familie- og kulturkomiteen om endringer $i$ barnelova (barneperspektivet i foreldretvister).

Lovvedtak 81 (2012-2013)

Lov om endringer i barnelova (barneperspektivet i foreldretvister).

Innst. 186 S (2013-2014)

Innstilling fra kontroll- og konstitusjonskomiteen om grunnlovsforslag fra Per-Kristian Foss, Martin Kolberg, Marit Nybakk, Jette F. Christensen, Anders Anundsen, Hallgeir H Langeland, Per Olaf Lundteigen, Geir Jørgen Bekkevold og Trine Skei Grande om grunnlovfesting av sivile og politiske menneskerettigheter, med unntak av romertall X og romertall XXIV.

Prop. 112 L (2014-2015)

Endringer i straffeprosessloven (avh $\phi r$ av barn og andre sarlig sårbare fornormede vitner).

NOU 2016: 16

Ny barnevernslov. Sikting av barnets rett til omsorg og beskyttelse.

Prop. 75 L (2016-2017)

Endringar i pasient- og brukarrettslova, helsepersonellova m.m. (styrking av rettsstillinga til barn ved yting av helse-og omsorgstenester m.m).

Innst. 361 L (2016-2017)

Innstilling fra helse- og omsorgskomiteen om Endringar $i$ pasient- og brukarrettslova, helsepersonellova, m.m. (styrking av rettsstillinga til barn ved yting av helse-og omsorgstenestar m.m.). 
Prop. 169 L (2016-2017)

Innst. 151 L (2017-2018)

NOU 2019: 5

BLD (2019)
Endringer i barnevernloven $\mathrm{mv}$. (bedre rettssikkerhet for barn og foreldre).

Innstilling fra familie- og kulturkomiteen om Endringer $i$ barnevernloven $m v$. (bedre rettssikkerhet for barn og foreldre.

Ny forvaltningslov Lov om saksbehandlingen i offentlig forvaltning (forvaltningsloven).

Høringsnotat - Forslag til ny barnevernslov. 2019.

https://www.regjeringen.no/conten-

tassets/7a124c63b81b487e9d79ae44b73a2b70/horings-

notat-ny-barnevernslov---april-2019-.pdf hentet

12.10.19.

Kunngjøringer av vedtatte grunnlovsendringer

FOR-2014-05-14-628 Kunngjøring av Stortingets vedtak 13. mai 2014 om endringer $i$ Grunnloven.

FOR-2014-06-20-778 Kunngjøring av Stortingets vedtak 27. mai 2014 om redigert versjon av Grunnloven kapittel E. og F. som følge av vedtatte grunnlovsforslag om menneskerettigheter.

\section{Rettspraksis}

Høyesterettsavgjørelser

Rt. 2009 s. 1261.

Rt. 2014 s. 530.

Rt. 2015 s. 155.

Rt. 2015 s. 1388.

HR-2016-2171-A.

HR-2016-2314-U.

HR-2017-1996-U.

HR-2018-2096-A. 
HR-2019-1230-A.

Lagmannsrettsavgjørelser

LF-2017-152073.

LG-2018-55392.

LH-2018-61825-2.

LB-2019-53890.

LB-2019-67035.

Internasjonale kilder

Konvensjoner

Barnekonvensjonen De forente nasjoners internasjonale konvensjon 20. november 1989 om barnets rettigheter (engelsk og fransk språkversjon)

SP

De forente nasjoners internasjonale konvensjon 16. desember 1966 om sivile og politiske rettigheter.

Wien-konvensjonen Wien-konvensjonen om traktatretten av 23. mai 1969.

FNs barnekomité

Avsluttende merknader

Concluding observations: Norway (CRC/C/NOR/CO/4). Dokumentdato: 11.05.2009.

Concluding observations: Norway (CRC/C/NOR/CCO/5-6). Dokumentdato: 04.07.2018.

Generelle kommentarer

Generell kommentar nr. 12 General Comment No. 12 (2009) The right of the child to be heard $\mathrm{CRC} / \mathrm{C} / \mathrm{GC} / 12$. 